\title{
La tecnologia Polaroid fra linguaggi e distanze. Una suggestione videografica per i tempi di Covid-19
}

Ornella Zerlenga

Vincenzo Cirillo

Abstract

A partire dal secolo scorso, la tecnologia Polaroid ha posto le basi per la formulazione di un innovativo linguaggio visivo. In questo articolo e al tempo della quarantena da Covid-19, il formato quadrato della stampa fotografica Polaroid (delimitato da una cornice bianca) viene interpretato come metafora dell'immagine mentale della 'finestra' da cui l'isolamento sociale ha costretto a osservare il mondo, ridisegnando il concetto stesso di 'distanza' in termini di 'vicinato'.

Inserito all'interno del disciplinare del disegno, il contributo affronta il tema della connessione creativa fra disegno (analogico-digitale) e fotografia nell'ambito della progettazione di una narrazione audiovisiva sotto forma di spot pubblicitario di durata breve.

\section{Parole chiave}

spazi-filtro, Polaroid, linguaggio foto-grafico, videografica, comunicazione multimediale.

La tecnologia Polaroid come connessione creativa fra disegno, fotografia e narrazione audiovisiva (elaborazione grafica di Vincenzo Cirillo).

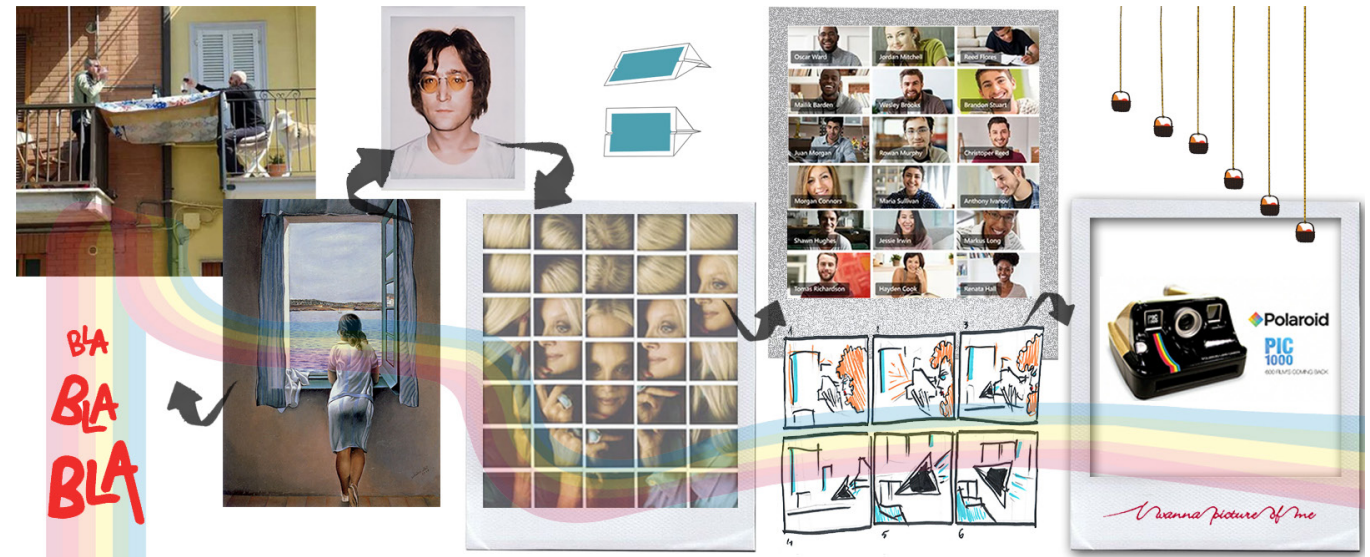




\section{Introduzione}

È opinione critica che le città, gli uffici, le piazze e i luoghi di aggregazione non più praticati nei giorni di lockdown non saranno più gli stessi dopo la pandemia di Covid-19 [Paoloni, Tutino, 2020]. II modo di abitare e pensare di tantissime persone è decisamente cambiato in un arco temporale di pochi mesi. E, assieme alle loro abitudini ed esigenze, sono mutati inevitabilmente anche gli spazi necessari destinati al loro soddisfacimento. Ė necessario accogliere nelle case uno spazio dedicato al lavoro? Oppure, accostare alle arterie viarie delle città grandi percorsi pedonali per mantenere le distanze? E quale ruolo bisognerebbe assegnare ai parchi urbani? Tutto dovrà essere ripensato?

Questi interrogativi sono stati già in parte accolti e sperimentati negli ultimi decenni da architetti, ingegneri e designer attraverso la formulazione di progetti strategici e realizzazione di città ecosostenibili per la riduzione del congestionamento urbano [ucci 2018, pp. 17-2।].

Fig. I. Gli spazi di filtro come luoghi di interazione sociale

durante la pandemia da Covid-19.
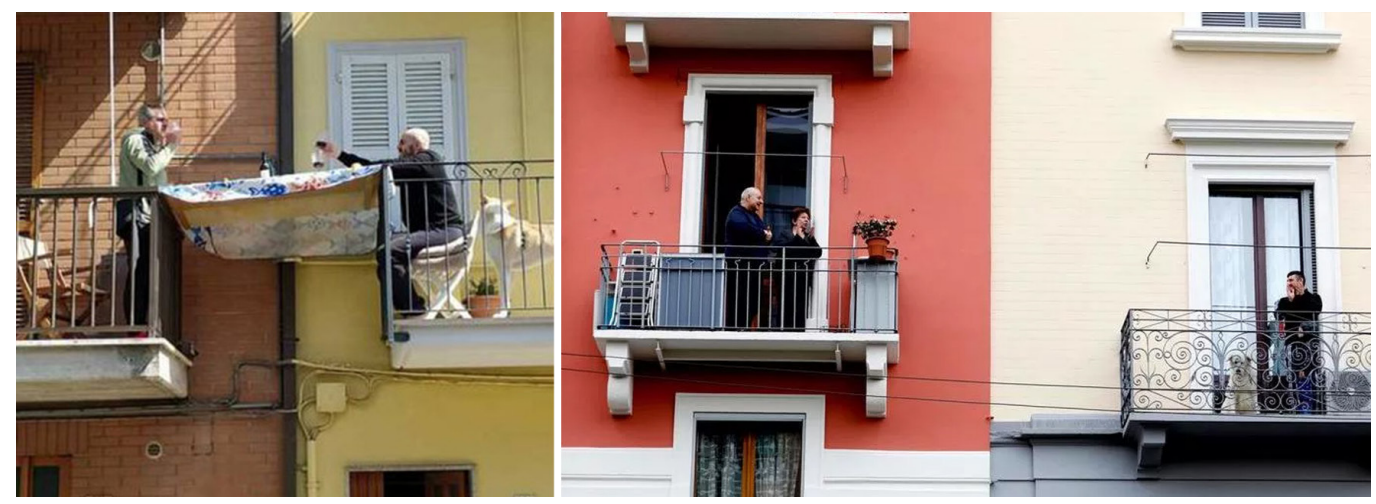

II tutto, però, quasi sempre in una dimensione a grande scala. La pandemia di Covid- I9, con il conseguente fenomeno di distanziamento sociale, ha invece dimostrato che il nuovo disegno di progetto delle città e delle sue periferie deve ri-partire da una scala più piccola riprendendo il concetto di 'vicinato'. Anche se da sempre luogo deputato all'abitare per contiguità residenziale e/o insieme di affinità etniche e condizioni sociali, nell'arco del secolo scorso il concetto di 'vicinato' è profondamente mutato a valle di una connessione 'globale' senza precedenti. Su queste premesse e inserito all'interno del disciplinare del disegno grafico, il presente contributo propone una duplice riflessione sul tema della 'connessione'. La prima, scatu-

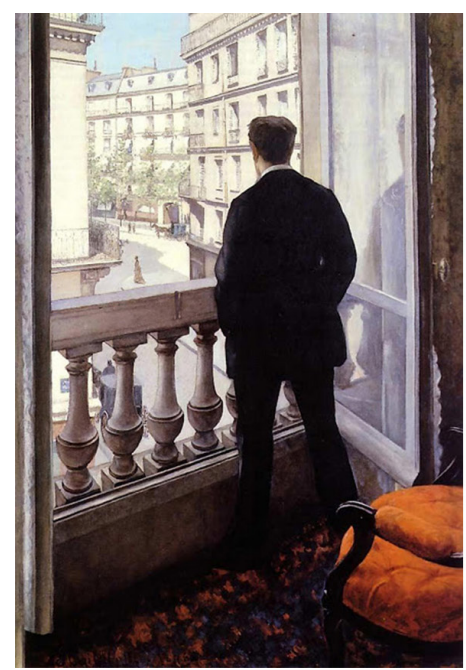

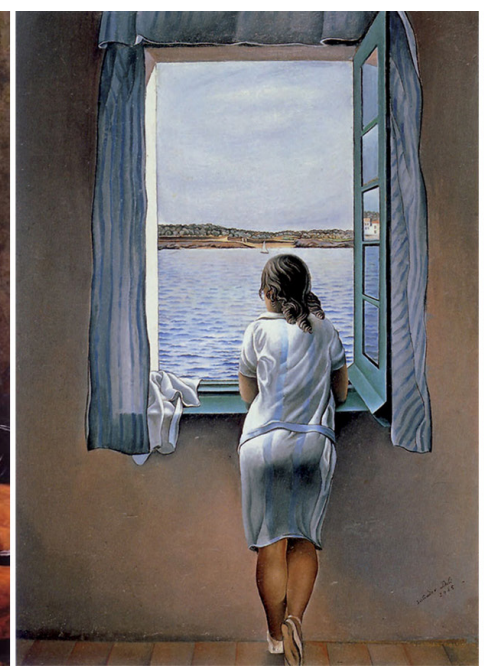

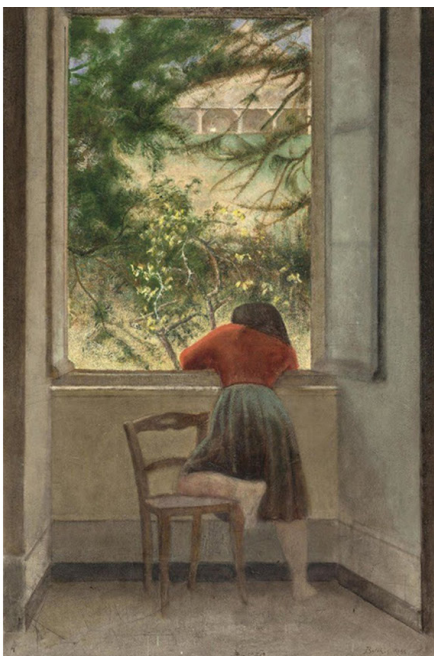

Fig. 2. Da sinistra: Gustave Caillebotte, Giovane uomo alla finestra, 1875; alla finestra, 1925; Balthus, Ragazza alla finestra, 1955. 
rita dalla crisi pandemica stessa, è riconducibile alla volontà dell'uomo (animale sociale) di essere nuovamente partecipe degli eventi collettivi, che all'improvviso gli sono stati negati. La sua condivisione sociale (e dunque fisica) nei casi migliori è stata limitata ai soli contesti abitativi definibili di pertinenza, intermedi, di filtro come i sistemi di accesso alle residenze: androni, cortili, scale [Zerlenga 2000]. Al contempo, spazi privati come logge, giardini, terrazzi, balconi, finestre - in passato caratterizzati da una notevole valenza progettuale - sono divenuti in tal senso i veri spazi di 'espiazione sociale' della quarantena, valvole di decompressione nella connessione fra interno ed esterno di cui non è più possibile fare a meno (fig. I). La seconda riflessione, invece, indaga la connessione fra fotografia e disegno: due linguaggi grafici di comunicazione visiva che, qui integrati in uno spot video-grafico pubblicitario sull'uso della macchina fotografica
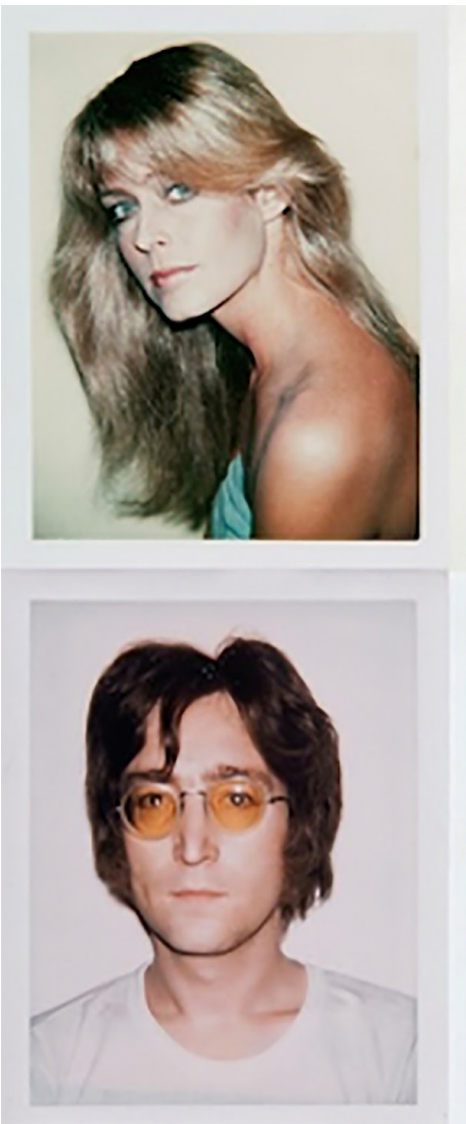

Fig. 3. Ritratti di Andy Warhol realizzati con il dispositivo Polaroi
(1970-1987).

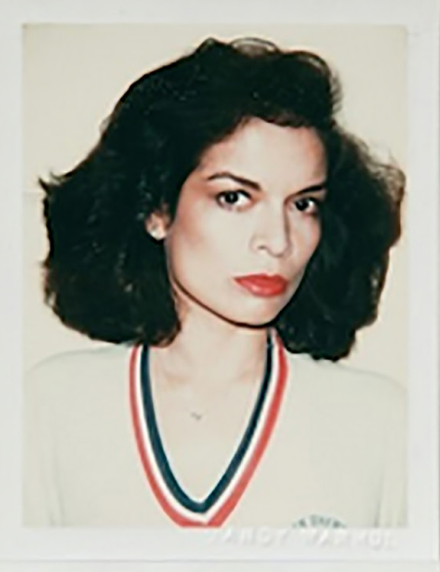

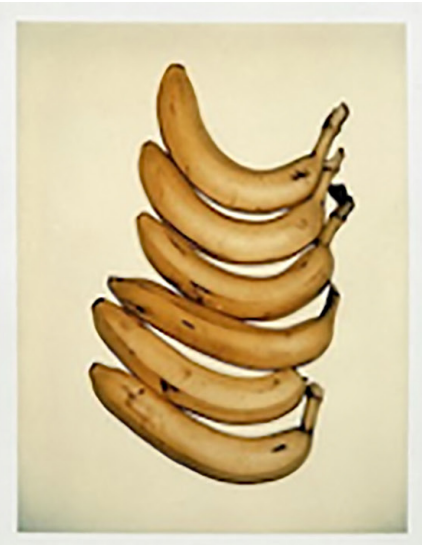
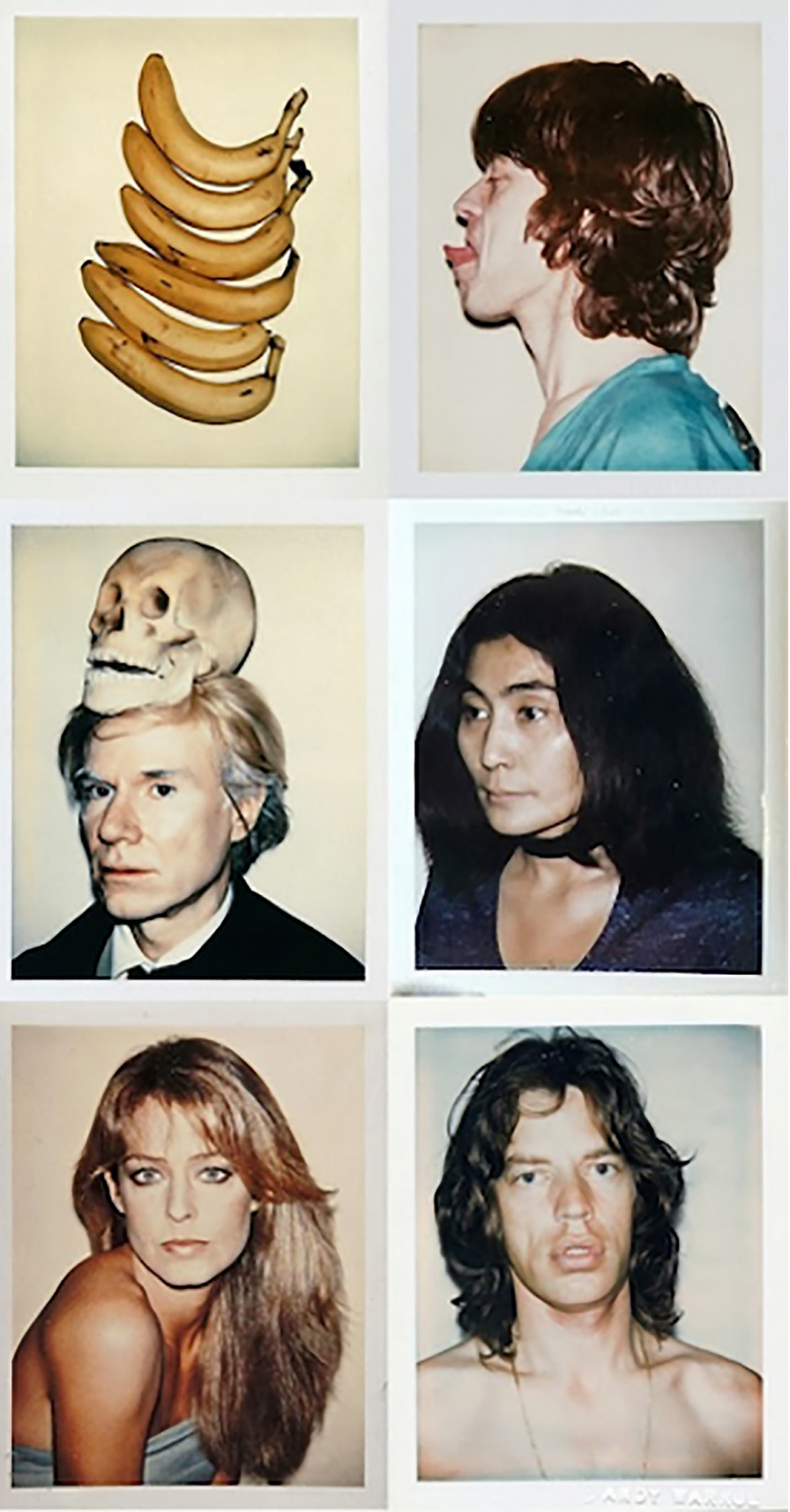
Fig. 4. Ritratti Polaroid di Julian Schnabel realizzati in grande formato $(50,8 \times 60,96 \mathrm{~cm})$.
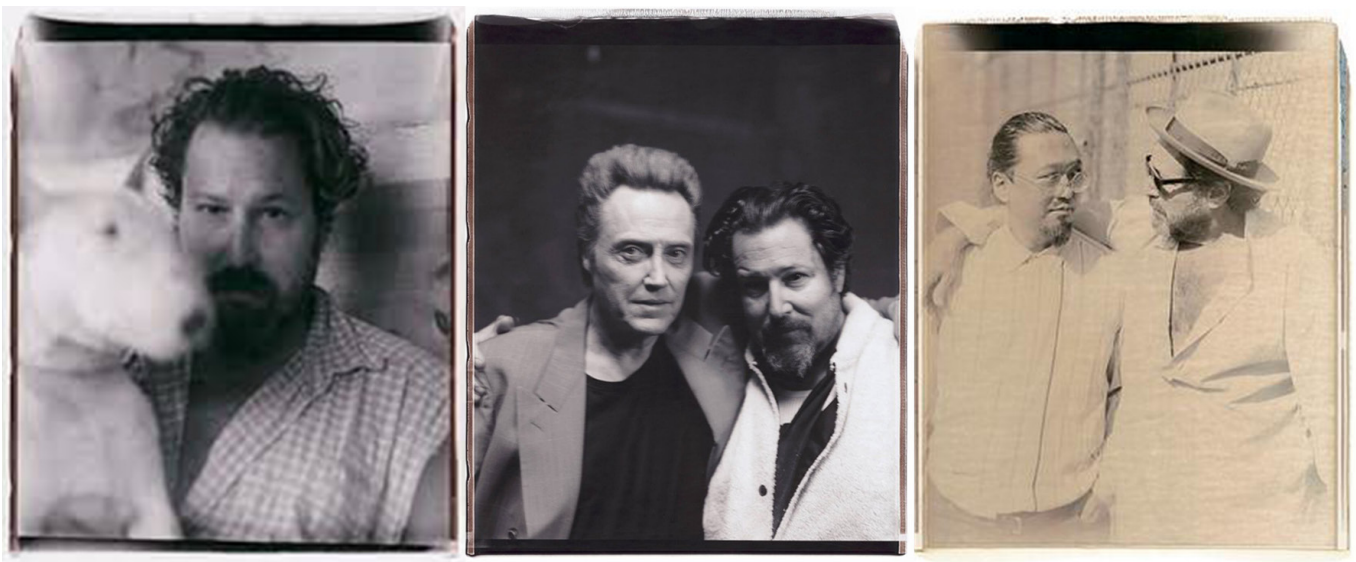

Polaroid, veicolano il tema del distanziamento sociale causato dalla crisi pandemica. In tal senso, il dispositivo analogico Polaroid è stato scelto come focus su cui sviluppare una riflessione congiunta su 'linguaggi, tecnologie e comunicazione a distanza'. Una scelta, quest'ultima, non casuale ma fondata sulle possibilità grafiche insite in un'icona come la Polaroid [Earls, Rohani 2005] (V.C.).

\section{Il dispositivo Polaroid e la narrazione 'a distanza'}

L'immagine mentale più radicata e diffusa del dispositivo analogico Polaroid è quella associata alla genesi di una fotografia istantanea di forma quadrata, delimitata da una cornice bianca e accompagnata da uno spazio sottostante dove poter scrivere quello che si vuole. In tal senso, la scena raffigurata 'inquadra', al pari di una finestra, un particolare momento, un luogo, un'emozione ripresa dall'esterno [Ghirri 1998, p. 23]. Si può pertanto desumere che, sin dalla sua origine, la Polaroid (come la fotografia e il disegno) si afferma come un metodo di rappresentazione grafica (nel senso di imprimere un segno, la luce, su un supporto) mentre, al contempo, il prodotto Polaroid (ovvero la foto istantanea) può essere interpretato un atto comunicativo, capace di veicolare un atteggiamento di pensiero, uno stato d'animo, un movimento artistico o culturale, una moda, o anche gli stessi elementi materiali o culturali che per tradizione o per consuetudine li esprimono [De Rubertis 1994].

Diversamente dalle correnti artistiche di fine '800 e inizio '900, nelle quali la pittura assegnava spesso all'elemento architettonico della finestra un ruolo esclusivo di osservazione dall'interno verso l'esterno, stante i soggetti di spalle (fig. 2), durante la seconda metà del '900 il dispositivo Polaroid inverte il punto di vista attribuendo alla 'finestra' un ruolo di

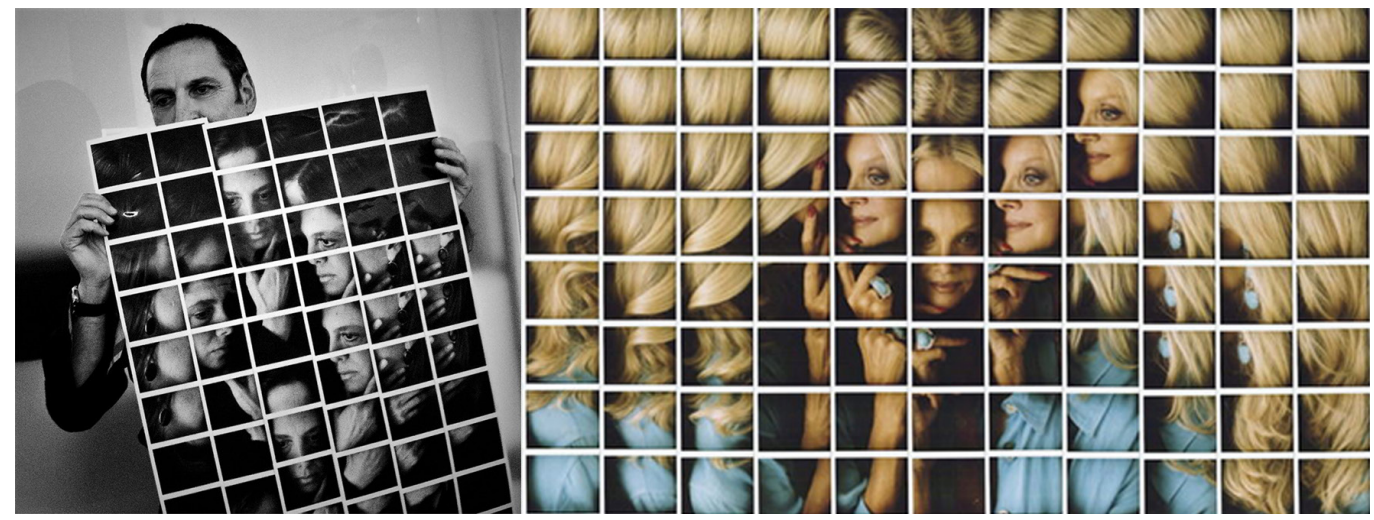




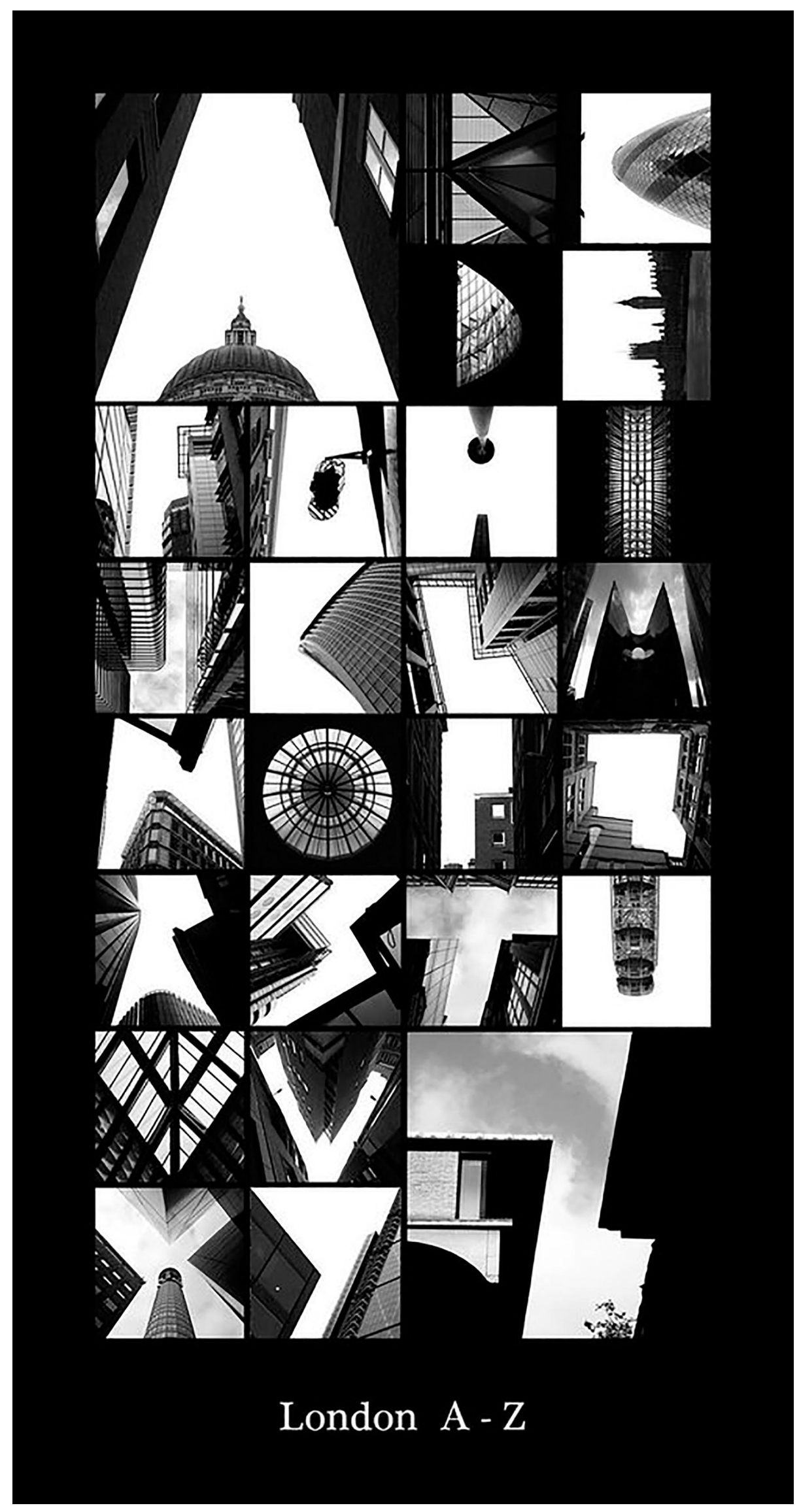

Fig. 6. Linguaggio visivo foto-grafico del progetto Alphatecture di Peter Defty realizzato con i concetto di 'vicinanza'
degli edifici a Londra (2005-2010) 
protagonismo assoluto: essa diventa la cornice attraverso cui il mondo osserva l'uomo. Questo strumento ha rappresentato un fenomeno di moda durante gli anni '50, una vera e propria forma di comunicazione di massa oltre a costituire un linguaggio narrativo d'arte del tutto originale. Prima della grande esplosione digitale odierna è tornato in auge per vari anni e, attualmente, pur se come fenomeno di nicchia, la comunità analogica di polaroiders è sempre più vasta.

Nell'era del digitale, la Polaroid infatti si inserisce come un elemento nostalgico legato all'importanza della tecnologia istantanea ma soprattutto alla sua natura analogica e al rischio che, nella più elementare ipotesi, la fotografia o esce bene oppure è un totale fallimento. Ed è proprio questa eventualità che attira numerosi artisti ad utilizzarla. Essa rappresenta uno strumento creativo unico. Non esiste la possibilità di una post-produzione e la creatività è concentrata tutta nell'applicazione di 'tecniche' semplici e/o complesse, che permettono di alterare lo scatto compiuto attraverso i composti chimici contenuti all'interno dei film [Thormod Carr 1997].

Anche oggi il fine non è cambiato: la Polaroid è sempre intesa come un mezzo per narrare qualcosa. Negli ultimi decenni del '900, questo dispositivo fa un passo avanti e comincia a configurarsi come uno storyboard per definire la visione personale di immagini più forti con una 'storia' che unisce il tutto. Si pensi, ad esempio, ai ritratti del pittore, grafico e illustratore Andy Wharol (1928-1987), che attraverso l'uso della Polaroid inventò uno stile rivoluzionario e personalissimo, ritraendo con questo dispositivo i protagonisti del cinema del suo tempo e rafforzandone l'immagine iconica [Hunt 2007] (fig. 3), oppure alle creazioni in grande formato di Julian Schnabel, che raffigurava luoghi familiari e/o abbracci con colleghi e amici secondo una visione del tutto anticonvenzionale [Hollein 20 I 8] (fig. 4). Questa intima rappresentazione dell'uomo porterà successivamente il Polaroid Istant Photographer Maurizio Galimberti alla realizzazione di 'mosaici artistici umani' (e architettonici) [Mutti 2005; Galimberti 20 I8], allargando gli orizzonti e lo spazio della vista, rompendo gli schemi soliti della visione e portando l'occhio alla decodificazione di una narrazione ben costruita dei soggetti fotografati attraverso l'accostamento di numerose finestre, quasi uno step by step, che a partire dai capelli muove verso il viso (fig. 5).

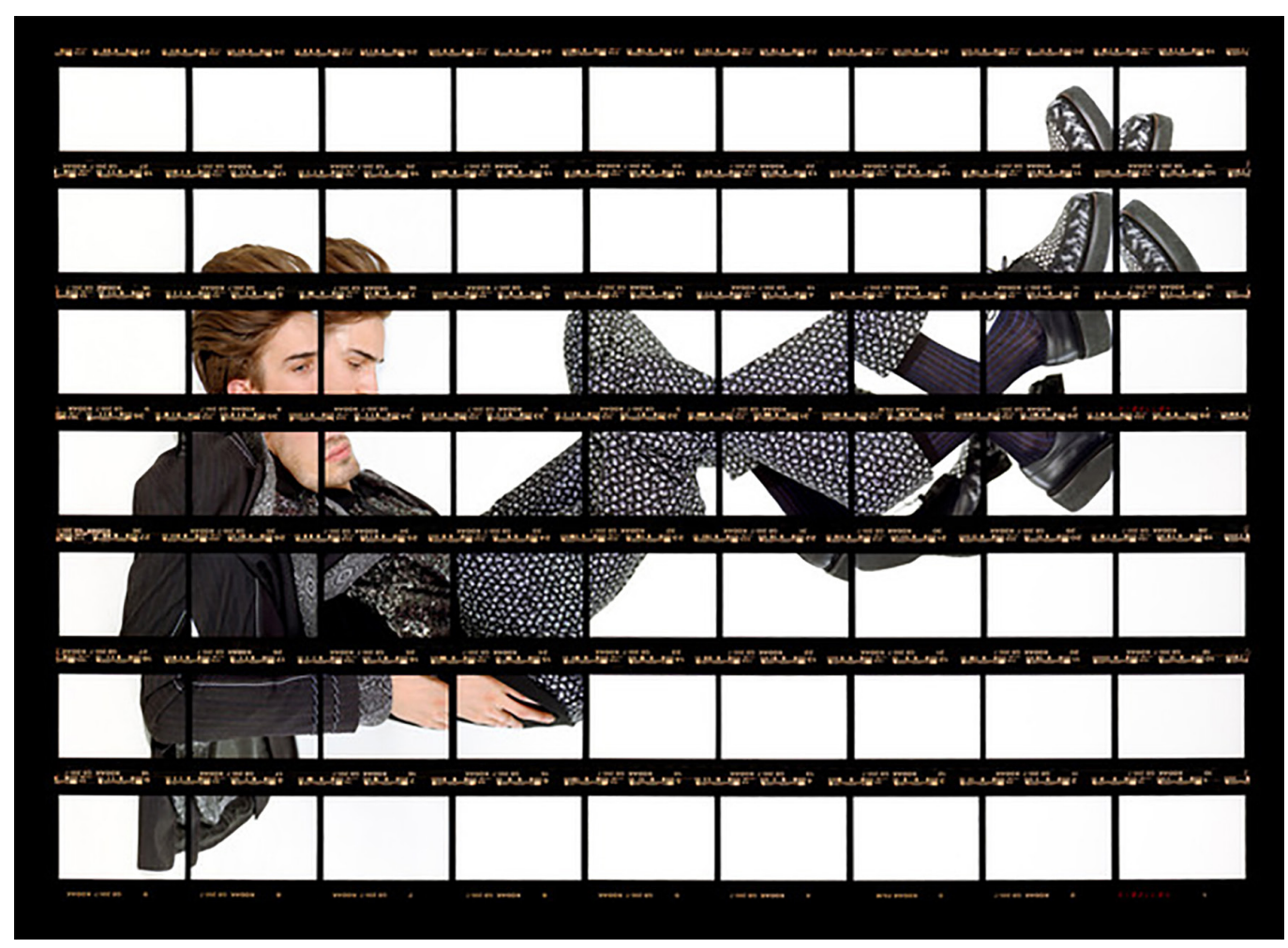


Dallo scorso decennio, la grande esplosione di calcolo (sempre in continua evoluzione) ha portato queste 'finestre' visive verso una dimensione esclusivamente digitale. Basti pensare, ad esempio, alle opere Alphatecture di Peter Defty (fig. 6) o Tango Metropolis di Thomas Kellner, frutto di una perfetta fusione dei diversi linguaggi visivi della fotografia (e anche della tipografia nel primo) (fig. 7), che hanno continuato a narrare la realtà filtrata attraverso la sensibilità informata dalla cultura di chi esegue lo scatto secondo un linguaggio comunicativo di ampia diffusione originato dal precursore analogico.

La Polaroid può essere pertanto e senza dubbio considerata uno dei primi strumenti di linguaggio visuale alla portata di tutti. E, se da un lato, ha introdotto una cultura artistica basata sull'introspezione e sulla rappresentazione attenta delle emozioni umane, la sua innovazione fotografica ha anche avviato il processo del 'far presto', portando la fotografia a non essere più la stessa opera paziente che era prima del suo ingresso.

Infine, emblematica risulta l'odierna e globale 'finestra visiva' da essa derivata, che ha letteralmente invaso la nostra sfera quotidiana durante la pandemia da Covid- 19 all'interno dei dispositivi di comunicazione e formazione a distanza come Microsoft Teams, Google Meet, Zoom, ecc. (fig. 8). In questi dispositivi, ognuno risulta 'incorniciato' in una 'video-polaroid' di derivazione galimbertiana, che può accrescersi sensorialmente attraverso 'sezioni multidimensionali' con una vastissima gamma di opzioni. Questo fenomeno, profondamente attecchito nel nostro quotidiano, ha superato persino la griglia standardizzata delle bacheche dei social networks. Ecco dunque che, anche se in una dimensione virtuale, chiunque può essere in qualsiasi parte del mondo o, in compagnia in una sala virtuale, per rimpiazzare l'odierno "dramma dell'alienazione [...] dall'estasi della comunicazione" a distanza [Baudrillard 1997, p. II] (V.C.).

\section{II videoclip I'm a Picture come integrazione fra Polaroid e videografica}

L'idea di utilizzare uno spot videografico, realizzato come prodotto pubblicitario della Polaroid, nasce dalla applicazione dell'attuale concetto di 'vicinato' durante il periodo di quarantena [Treleani, Zucconi 2020] agli spazi di filtro residenziali presenti nel suddetto videoclip.
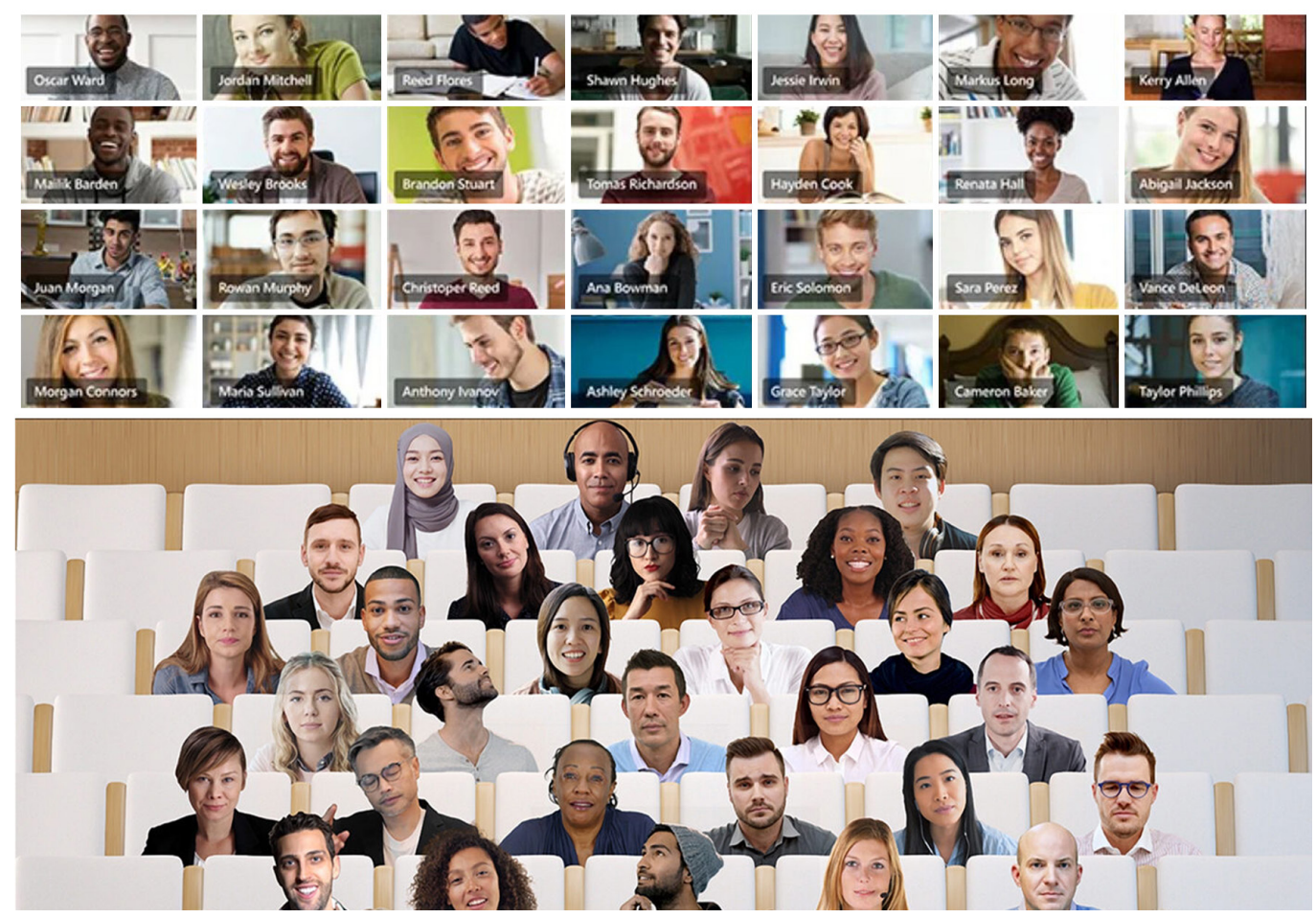

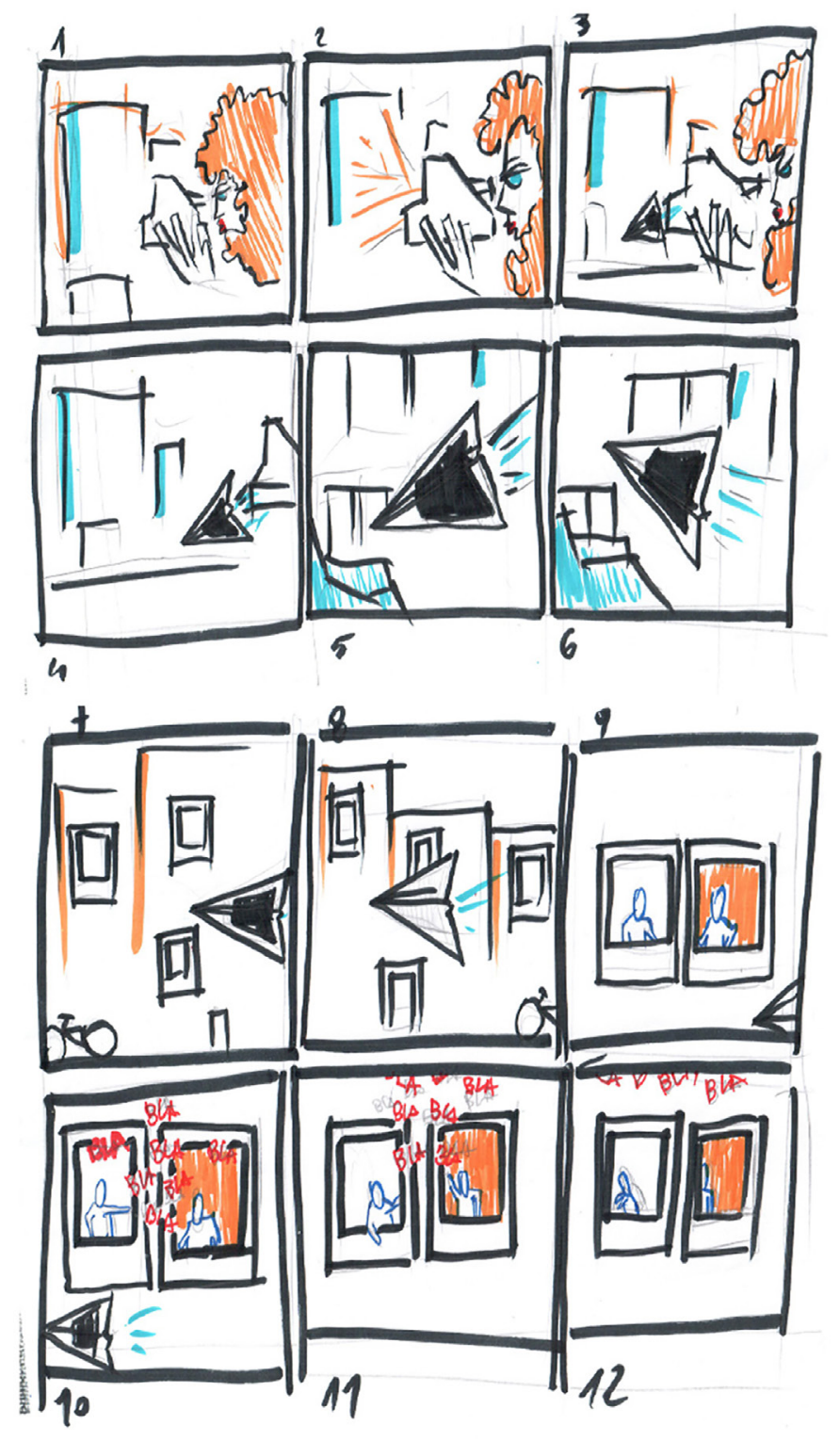

Il progetto di realizzazione del videoclip integra in un unico prodotto più forme della comunicazione: il disegno, sia analogico che digitale, per la creazione delle scene (fig. 9); la riproduzione vettoriale di elementi grafici per la connessione delle scene suddette; gli scatti fotografici, eseguiti con una macchina Canon e montati con la tecnica dello stop motion; il contesto sonoro di accompagnamento [Falcidieno 2006; 2008; 20 I0; Zerlenga 2007; 2020; Cirillo 20 19]. II videoclip è stato poi montato e assemblato con appositi programmi di video e music editing.

La storia narrata parte con la scena di una ragazza, che scatta una foto Polaroid. La fotografia scivola dallo scudo del dispositivo trasformandosi in un aereo di carta. L'aereo inizia a volare nella stanza per continuare su una parete bianca dove, velocemente, numerosi segni grafici lineari assumono gradualmente la forma di più palazzi visti frontalmente. L'areo di carta si infila in una delle numerose finestre (rappresentate dalle cornici delle Polaroid), che compongono le facciate degli edifici del quartiere, e la scena prende vita richiamando il tema del 'vicinato' attraverso scene di vita quotidiana ambientate negli spazi di filtro di finestre e balconi. Questi luoghi di filtro sono anche promotori di una comunicazione visiva e verbale a distanza. In tal senso, attraverso la messa a punto di una pubblicità di 
un prodotto vintage, la Polaroid per l'appunto, l'ambiente urbano e la vita di tutti i giorni mirano a rivalutare gli spazi quotidiani da tempo abbandonati dalla frenesia di movimento pre-pandemica. Successivamente, le scene si susseguono in una molteplicità di narrazioni quotidiane, che si legano fra loro secondo rapporti interpersonali 'a distanza'. Le scene, osservate dall'esterno, sono fra loro collegate attraverso disegni animati come il paniere, i cuori, le note musicali, l'onomatopea del parlare: simboli oramai della quotidianità Covid-19. Infine, un nastro nei colori Polaroid fuoriesce da una stanza, in cui una ragazza è in procinto di cantare, e conclude la storia posizionandosi al di sotto della macchina fotografia e componendo lo slogan (fig. I0).

La realizzazione dei set è avvenuta con la tecnica dello stop motion (e non tramite video) [Gasek 20 I7] per non allontanarsi troppo dallo stile 'fotografico' e comunicativo del dispositivo (fig. I I). Per il videospot è stata realizzato anche un accompagnamento sonoro dal ritmo cadenzato così da poter rimanere impresso nella mente quasi come una filastrocca da canticchiare. La stessa frase è cantata per quattro volte sia da una voce solista che da un coro festoso. Quest'ultimo richiama un messaggio di condivisione collettiva e rimanda ai cori sui balconi durante il primo lockdown (fig. 12). II brano musicale è stato composto interamente da Ivo Pisanti, poi mixato e registrato da Marco Musco e da un coro di sette giovani. La base musicale è stata realizzata con il programma di music editing GarageBand, al quale successivamente sono state aggiunte le voci registrate in sala di incisione. Formulato per essere facilmente memorizzato, il testo della canzone (e slogan del videospot) allude al consumo attuale delle immagini sui social networks (dove, ormai, si è immagine di sé stessi) [Menchetelli 2019] e recita "I'm a Picture, we are a Picture. I wanna Picture, picture of me" (O.Z.).
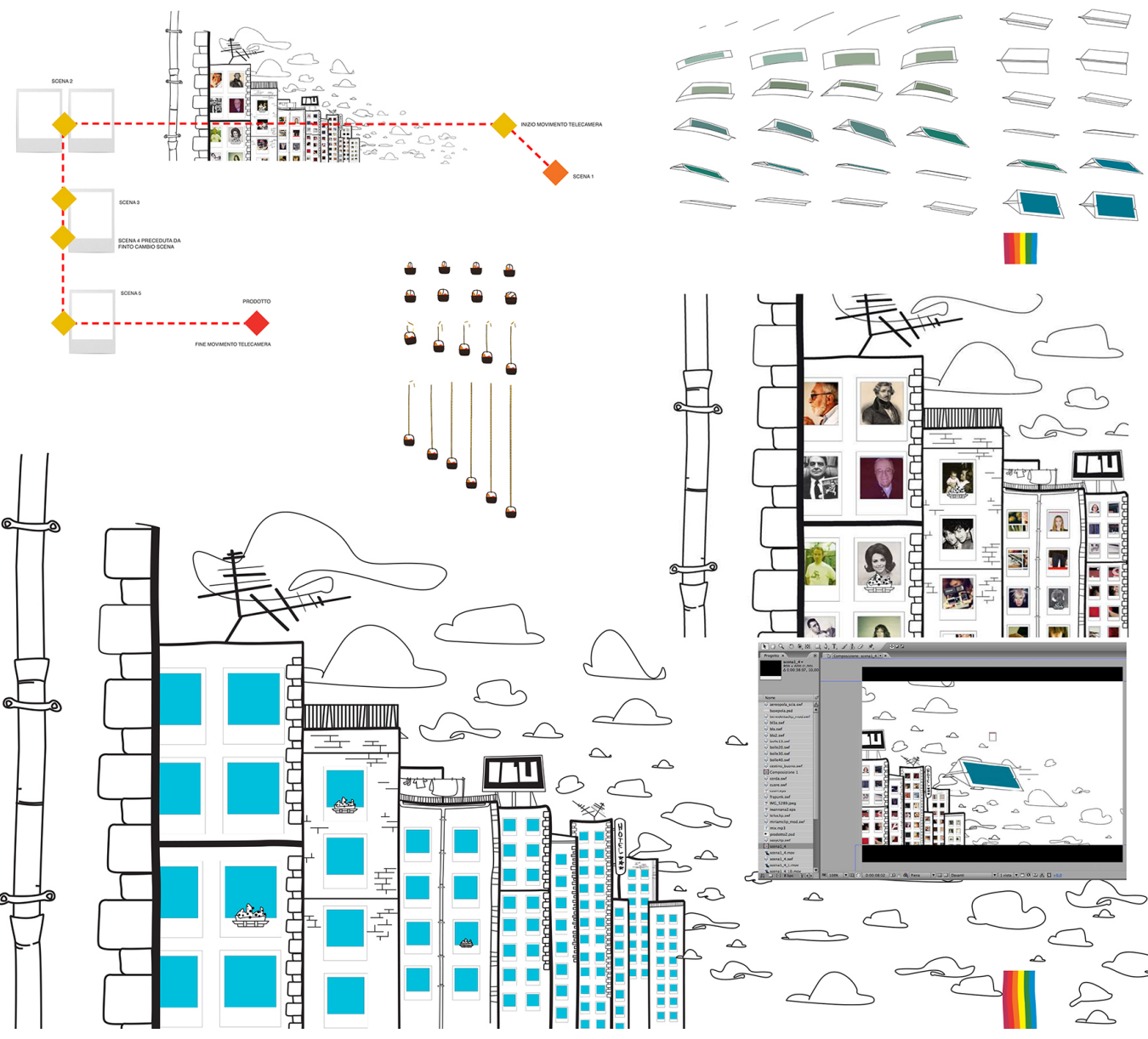

\section{III}
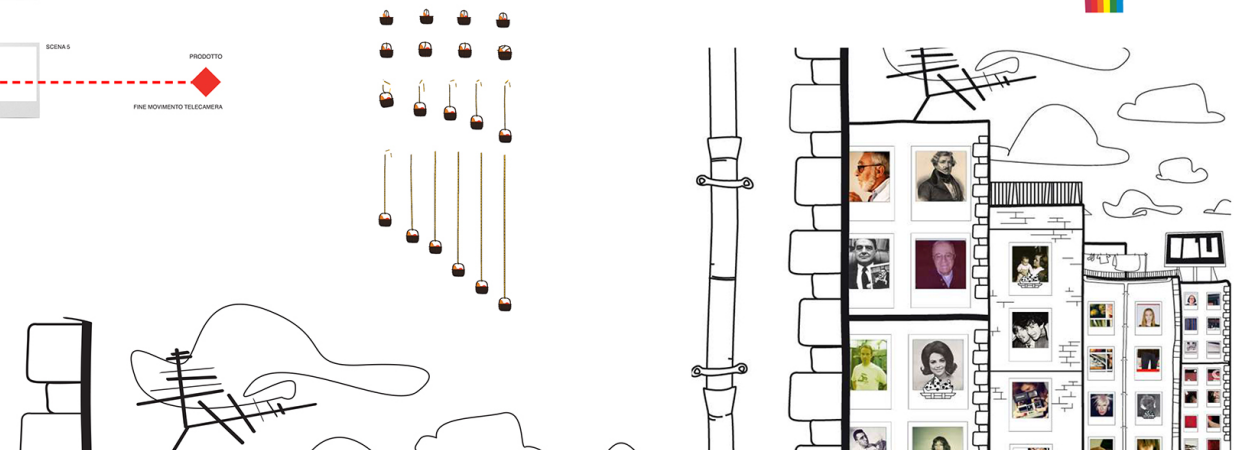

国盟国
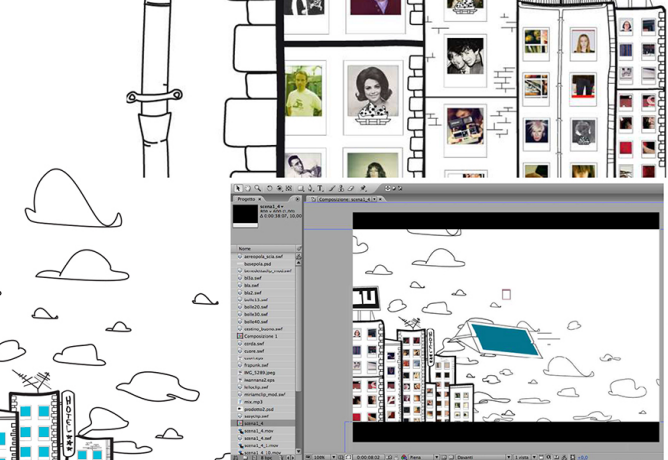

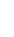

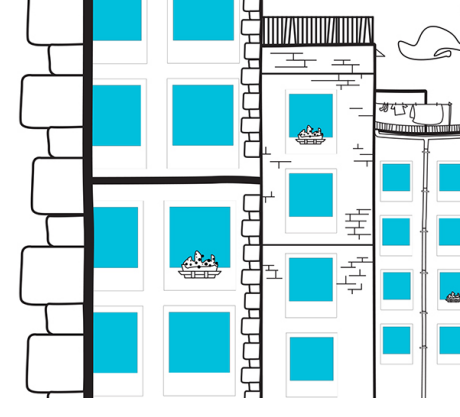

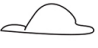

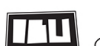

A 

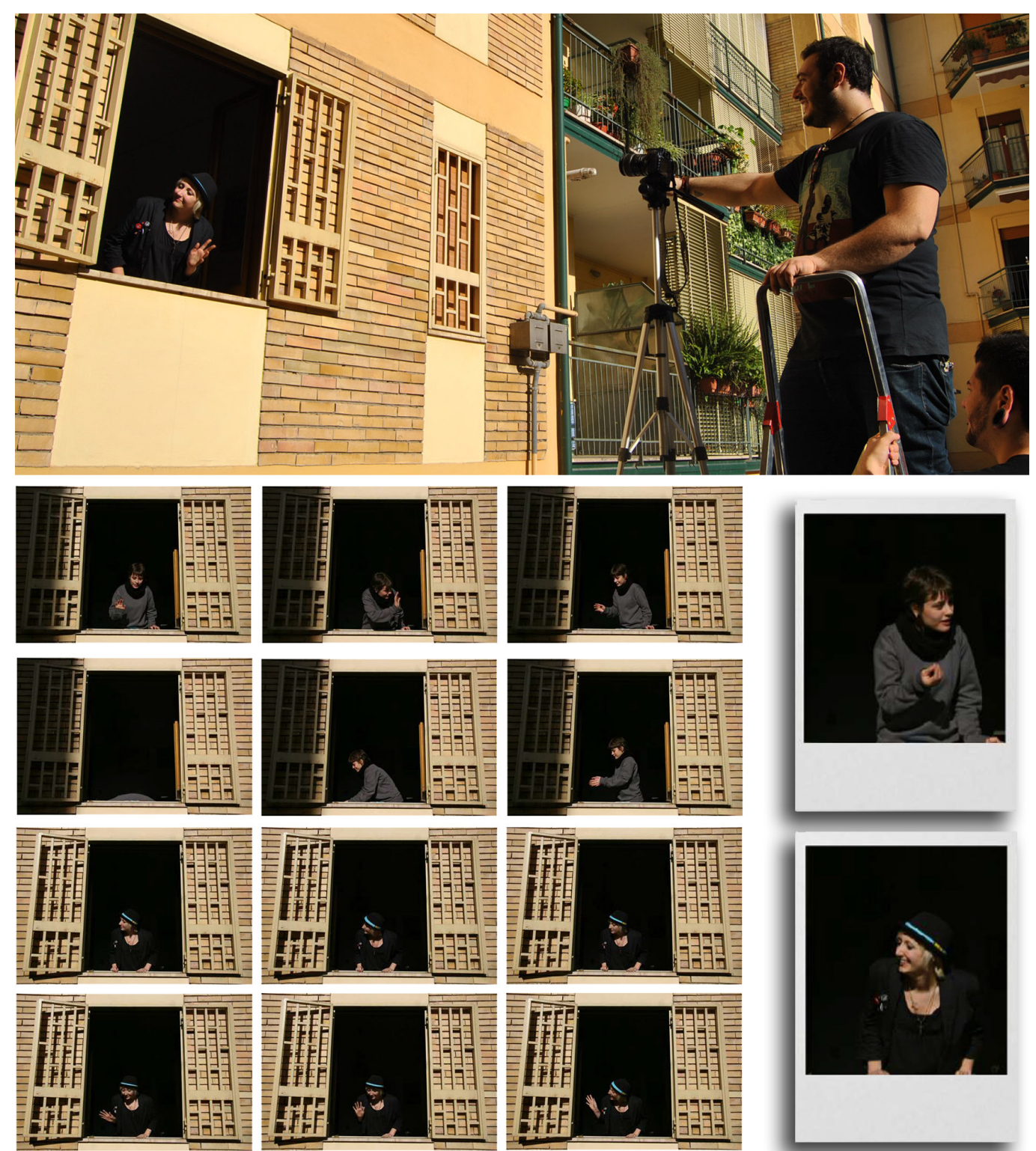

Fig. I I. Riprese delle

scene (fotogrammi) e

montaggio foto-grafico

in stop motion (riprese
disegni di Ivo Pisanti).

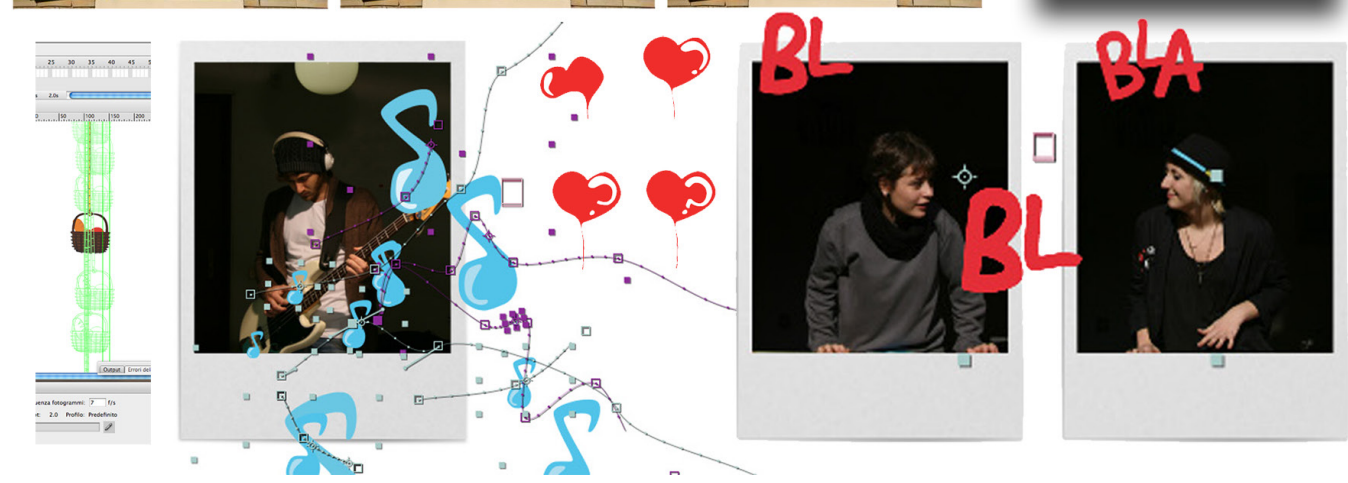




\section{Conclusioni}

Il tema della connessione fra linguaggi, tecnologie e distanze è stato sviluppato quale metafora attraverso la realizzazione di un prodotto multimediale in cui il disegno (nelle sue molteplici declinazioni) è stata la principale forma di comunicazione della storia narrata. II progetto, realizzato in ambito universitario [I], si configura come un videoclip pubblicitario del dispositivo analogico Polaroid, la cui narrazione audiovisiva sperimenta il rapporto creativo fra disegno (analogico-digitale) e fotografia nell'opinione culturale che, ai tempi della pandemia, l'attenzione alla città si è spostata sugli spazi di vicinato e sui luoghi di filtro a essi pertinenti da intendersi come occasione di ri-disegno plurifunzionale (O.Z.).
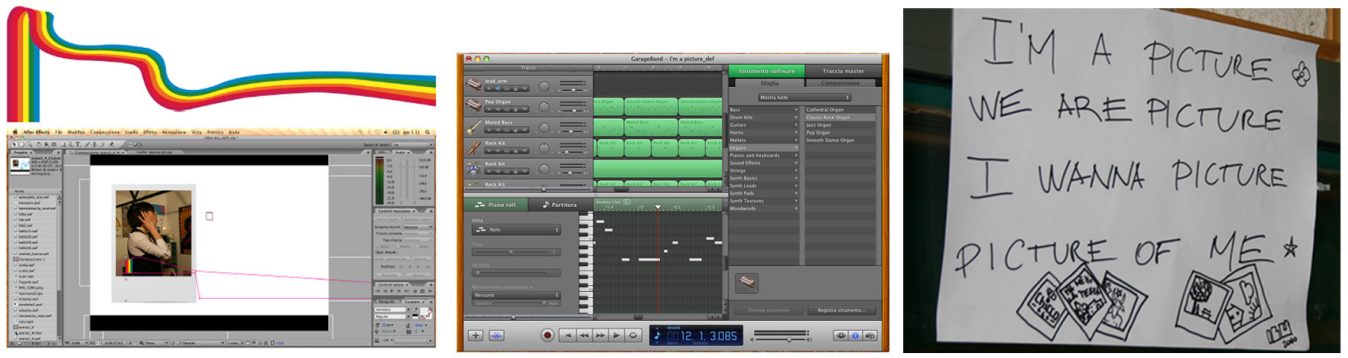

Fig. 12. Progettazione dell'accompagnamento sonoro e sequenza video dello spot (elaborazioni
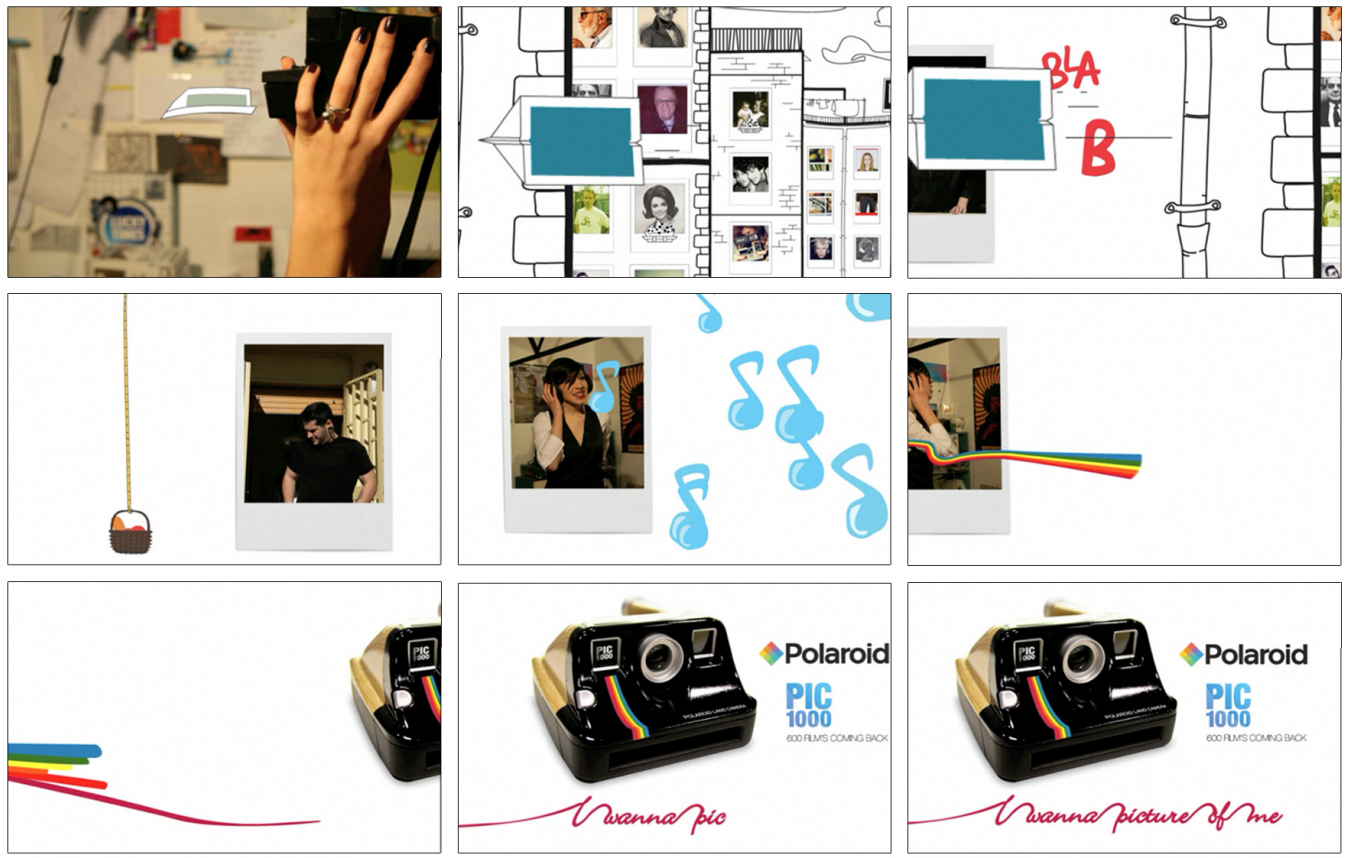

Note

[I] Con il coordinamento scientifico di Ornella Zerlenga, il progetto è stato sviluppato all'interno del Laboratorio di Graphic Creations da Ivo Pisanti (figg. 9-12).

\section{Riferimenti bibliografici}

Baudrillard J. (1997). L' altro visto da sé. Genova: Costa\&Nolan, p. I I. Ed. orig. 1987. L'autre par lui-Meme: Habilitation. Paris: Editions Galilèe.

CirilloV. (2019). Scrittura e multimedialità. Ridisegnare l'esperienza futurista /Writing and Multimedia. Redesigning the Futuristic Experience. In diségno, vol. 4, pp. 149-160.

Cirillo V.,Todisco I. (a cura di). (2020). Cratere degli Astroni. Concorso grafico 'Comunicazione etica per il pianeta'. Napoli: La Scuola di Pitagora. 
De Rubertis R. (1994). Il disegno dell'Architettura. Roma: La Nuova Italia Scientifica.

Earls A., Rohani N. (2005). Images of America Polaroid. Chicago: Arcadia Publishing.

Falcidieno M. L. (2006). Parola disegno segno. Comunicare per immagini. Segno, significato, metodo. Firenze: Alinea.

Falcidieno M. L. (2008). Il ruolo del disegno nella comunicazione. Firenze: Alinea.

Falcidieno M. L. (20I0). Comunicazione-rappresentazione. Testo, immagine, segno grafico. Firenze: Alinea.

Ford S., Forlizzi J., Ishizaki, S. (1997). Kinetic Typography: Issues in time-based presentation of text. In CHI97 Conference Extended Abstracts, pp. 269-270.

Galimberti M. (2018). Maurizio Galimberti. Ediz. Illustrata. Torino: FIAF.

Gasek T. (2017). Frame-By-Frame Stop Motion: The Guide to Non-Puppet Photographic Animation Techniques. Second Edition. Boca Raton: CRC Press.

Ghirri P. (Ed.). (1998). Luigi Ghirri - Polaroid - L'opera completa 1979-1983. Milano: Baldini\&Castoldi, p. 23.

Gombrich E. (1994). The Image and the Eye. London: Phaidon Press.

Hollein M. (2018). Julian Schnabel: Symbols of Actual Life. San Francisco: Fine Arts Museums of San Francisco.

Hunt T. (2007). Andy Warhol Polaroid Portraits. Tokyo: Miyake Fine Art.

Kathleen T. Carr (1997). Polaroid Transfers: A Complete Visual Guide to Creating Image and Emulsion Transfers. New York:Amphoto.

Menchetelli V. (2019). Images and more images. In img journal, I (I), 206-2I3.

Munari B. (20 I0). Da cosa nasce cosa. Roma: Laterza.

Mutti R. (2005). Maurizio Galimberti. Metacittafisica. Roma: Contrasto DUE.

Paoloni M., Tutino M. (a cura di). (2020). L'Italia ai tempi del Covid- 19. Tomo I. Milano: Wolters Kluwer Italia.

Spera M. (200 I). La progettazione grafica tra creatività e scienza. Roma: Gangemi editore.

Autori

Ornella Zerlenga, Università degli Studi della Campania Luigi Vanvitelli, ornella.zerlenga@unicampania.it

Vincenzo Cirillo, Università degli Studi della Campania Luigi Vanvitelli, vincenzo.cirillo@unicampania.it

Per citare questo capitolo: Zerlenga Ornella, Cirillo Vincenzo (2021). La tecnologia Polaroid fra linguaggi e distanze. Una suggestione videografica per i tempi di Covid-19/Polaroid Technology between Languages and Distances. A Video-graphic Suggestion for the Covid-19Times. In Arena A Arena M., Mediati D., Raffa P. (a cura di). Connettere. Un disegno per annodare e tessere. Linguaggi Distanze Tecnologie. Atti del $42^{\circ}$ Convegno Internazionale dei Docenti delle Discipline della Rappresentazione/Connecting. Drawing for weaving relationship. Languages Distances Technologies. Proceedings of the 42th International Conference of Representation Disciplines Teachers. Milano: FrancoAngeli, pp. $1294-1317$. 


\section{Polaroid Technology between Languages and Distances. A Video-Graphic Suggestion for the Covid-19 Times}

Ornella Zerlenga

Vincenzo Cirillo

\section{Abstract}

Since the last century, Polaroid technology has laid the foundation for the formulation of an innovative visual language. In this article and at the time of the Covid-19 quarantine, the square format of the Polaroid photographic print (delimited by a white frame) is interpreted as a metaphor for the mental image of the 'window' from which social isolation forced to observe the world, redesigning the very concept of 'distance' in terms of 'neighborhood'.

Inserted within the drawing specification, the contribution addresses the theme of the creative connection between drawing (analogue-digital) and photography as part of the design of an audiovisual narrative in the form of a short-term advertising spot.

\section{Keywords}

filter-spaces, Polaroid, photo-graphic language, videography, multimedia communication.

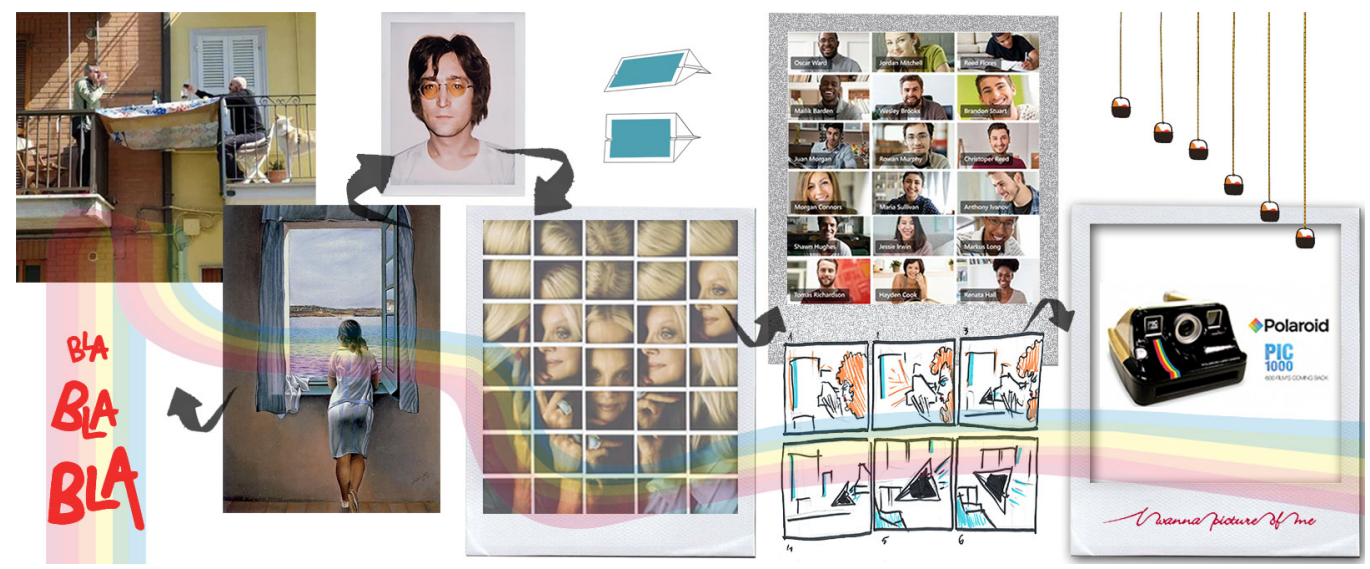




\section{Introduction}

It is a critical opinion that the cities, offices, squares, and meeting places no longer used in the days of lockdown will no longer be the same after the Covid-19 pandemic [Paoloni, Tutino 2020]. The way of living and thinking of many people has changed in a period of a few months. And, together with their habits and needs, the necessary spaces destined to satisfy them have also inevitably changed. Is it necessary to accommodate a space dedicated to work in homes? Or, to draw close to the main roads of the cities large pedestrian paths to keep the distance? And what role should be assigned to urban parks? Will everything have to be rethought?

These questions have already been partially accepted and experimented with in recent decades by architects, engineers, and designers through the formulation of strategic proj-

Fig. I. Filter spaces interaction during the Covid-19 pandemic.
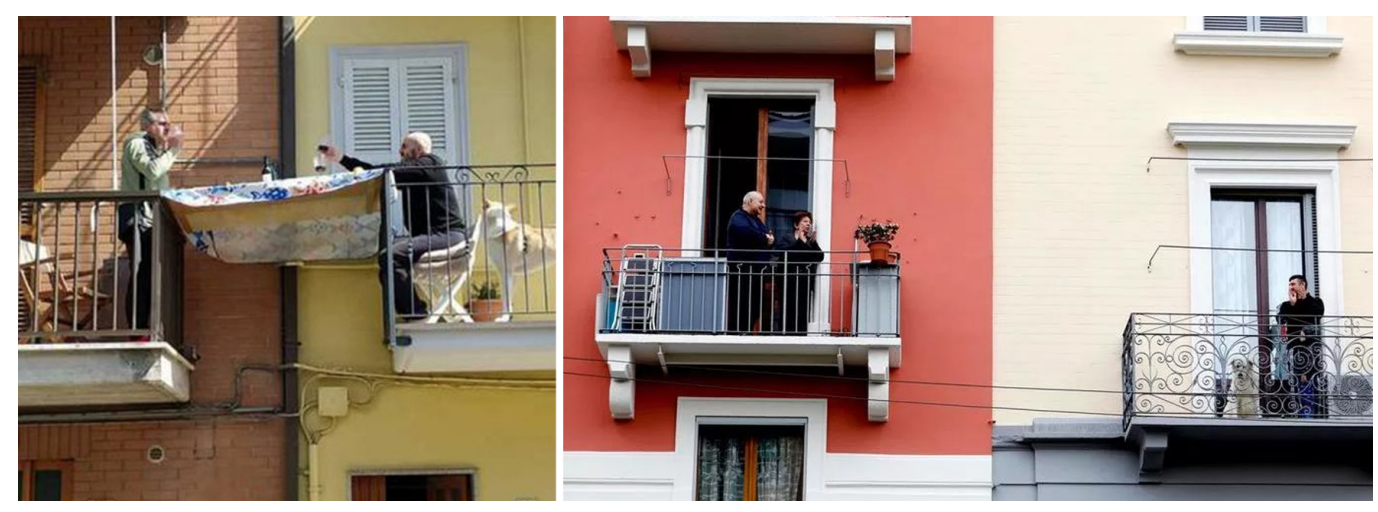

ects and the creation of eco-sustainable cities for the reduction of urban congestion [Tucci 20 I 8, pp. |7-2। ]. All this, however, almost always in a large-scale dimension. The Covid- I 9 pandemic, with the consequent phenomenon of social distancing, has instead shown that the new project design for cities and its suburbs must restart from a smaller scale, taking up the concept of 'neighborhood'. Although it has always been a place dedicated to housing due to residential contiguity and/or a combination of ethnic affinities and social conditions, over the course of the last century the concept of 'neighborhood' has profoundly changed following an unprecedented 'global' connection.
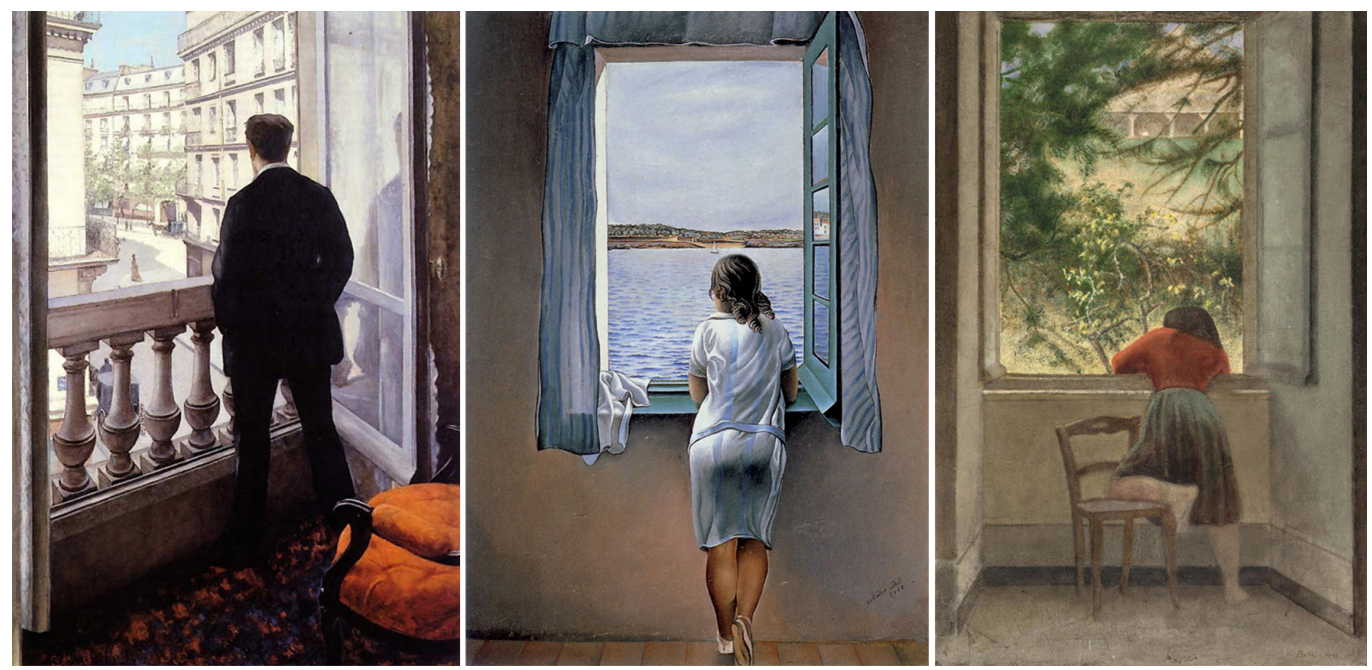

Fig. 2. From left: Gustave Caillebotte,Young man at the window, 1875 . Salvador Dali, The Girl at Window, 1925; Balthus, 
On these premises and inserted within the specification of graphic design, this contribution proposes a twofold reflection on the theme of 'connection'. The first, resulting from the pandemic crisis itself, is attributable to the will of man (social animal) to participate again in collective events, which had suddenly denied him. Its social (and therefore physical) sharing in the best cases has been limited only to definable living contexts of relevance, intermediate, filter such as access systems to residences: entrance-hall, courtyards, staircases [Zerlenga 2000]. At the same time, private spaces such as loggias, gardens, terraces, balconies, windows -in the past characterized by considerable design value- have become in this sense the real spaces of 'social expiation' of the quarantine, decompression valves in the connection between inside and outside of which it is no longer possible to do without (fig. I). The second reflection, on the other hand, investi-

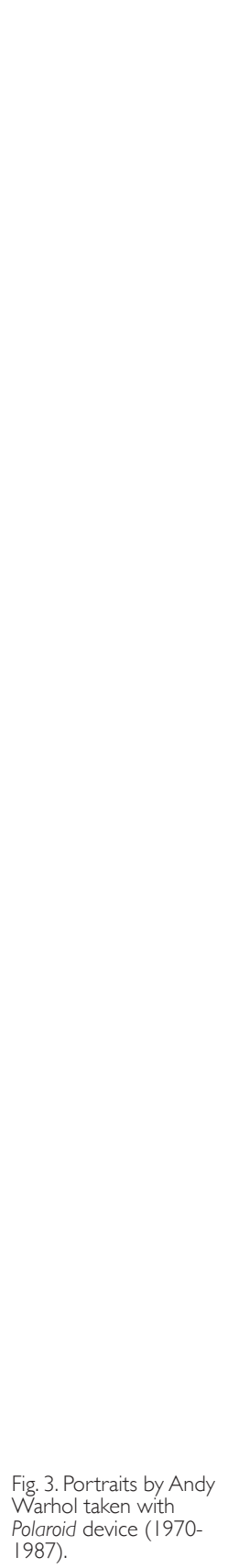

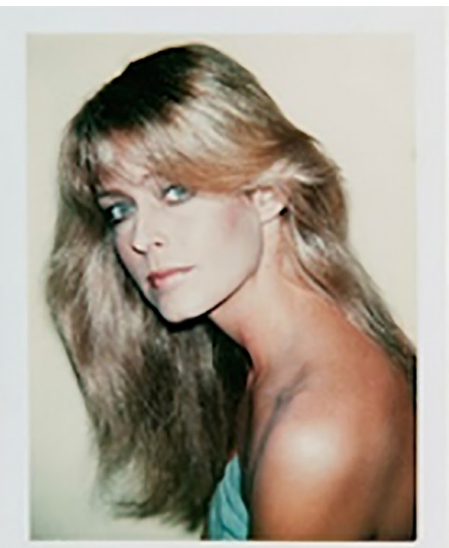
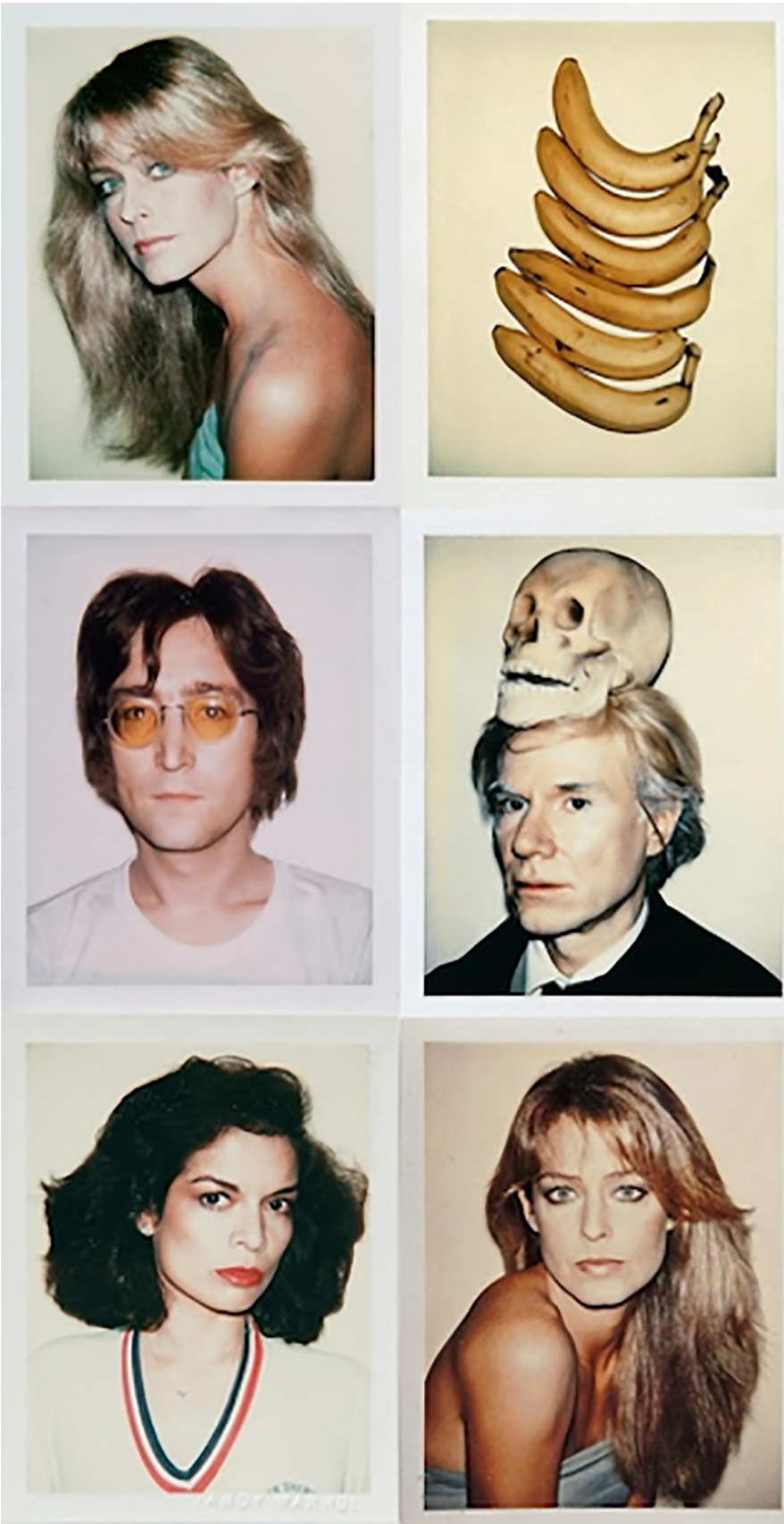
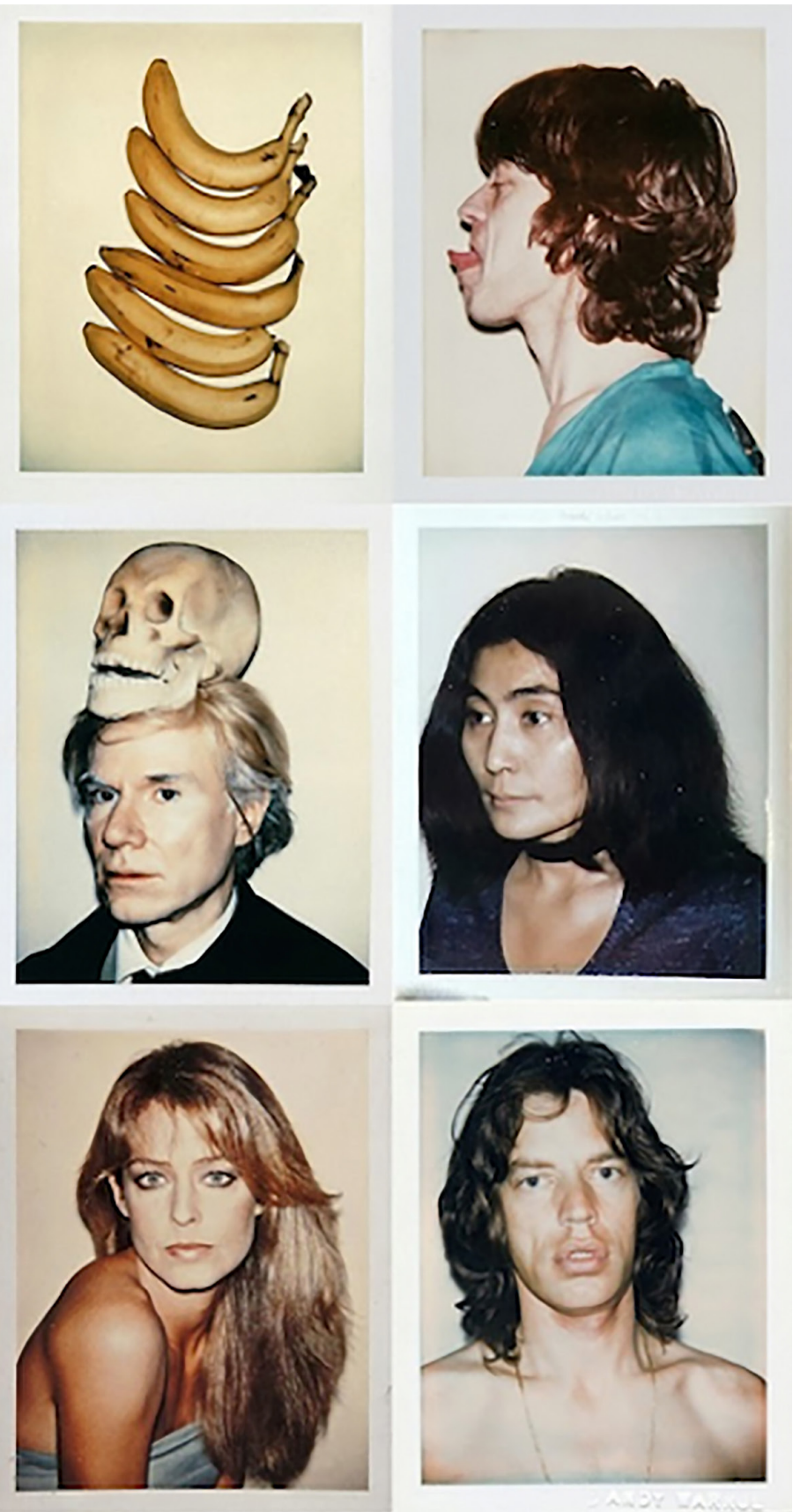
Fig. 4. Polaroid portraits by Julian Schnabel made in large format $(50.8 \times 60.96 \mathrm{~cm})$.
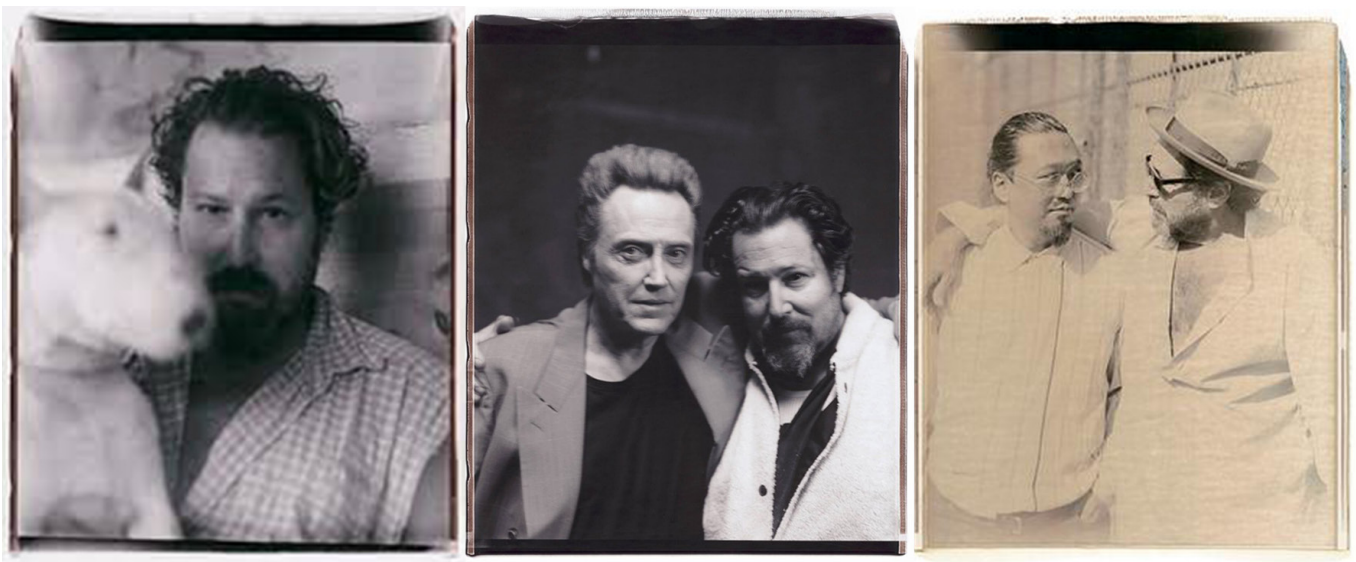

gates the connection between photography and drawing: two graphic languages of visual communication which, here integrated in a video-graphic advertising spot on the use of the Polaroid camera, convey the theme of social distancing caused by the pandemic crisis. In this sense, the Polaroid analog device was chosen as the focus on which to develop a joint reflection on 'languages, technologies and remote communication'. A choice not casual but based on the graphic possibilities inherent in an icon like the Polaroid [Earls, Rohani 2005] (V.C.).

\section{The Polaroid device and 'remote' narration}

The most rooted and widespread mental image of the Polaroid analog device is that associated with the genesis of a square-shaped instant photograph, delimited by a white frame, and accompanied by an underlying space where you can write whatever you want. In this sense, the scene depicted 'frames', like a window, a particular moment, a place, an emotion taken from outside [Ghirri 1998, p. 23]. It can therefore be assumed that, since its origin, the Polaroid (like photography and drawing) has established itself as a method of graphic representation (in the sense of impressing a sign, light, on a support) while, at the same time, the Polaroid product (i.e. the instant photo) can be interpreted as a communicative act, capable of conveying an attitude of thought, a state of mind, an artistic or cultural movement, a fashion, or even the same material or cultural elements that by custom they express them [De Rubertis 1994].

Different from the artistic currents of the late 19th and early 20th century, in which painting often assigned to the architectural element of the window an exclusive role of observation

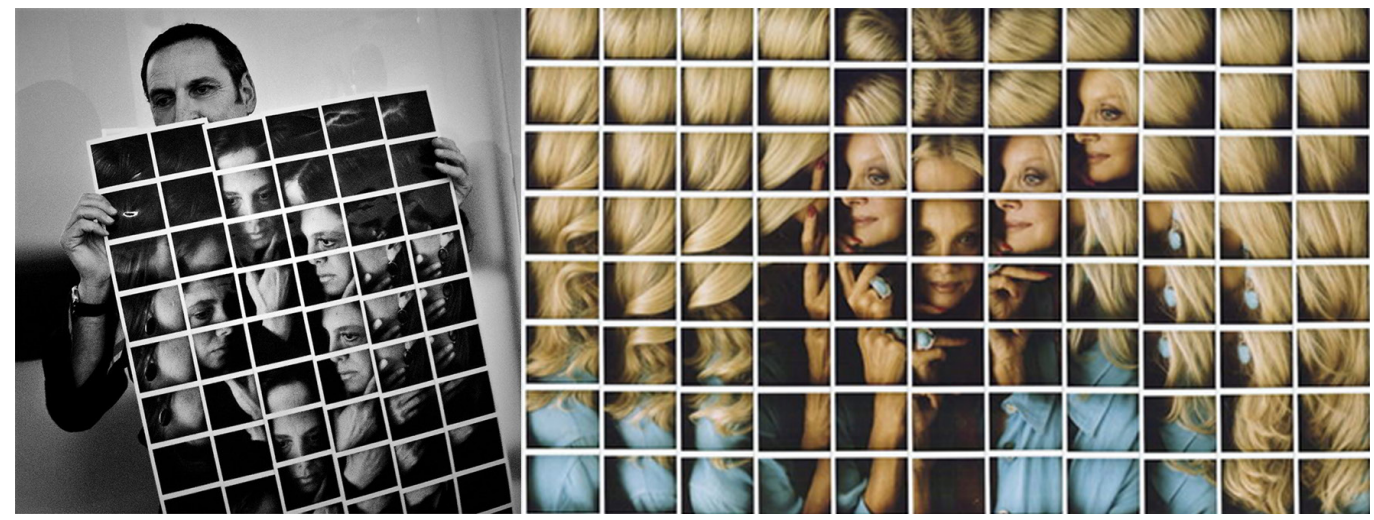




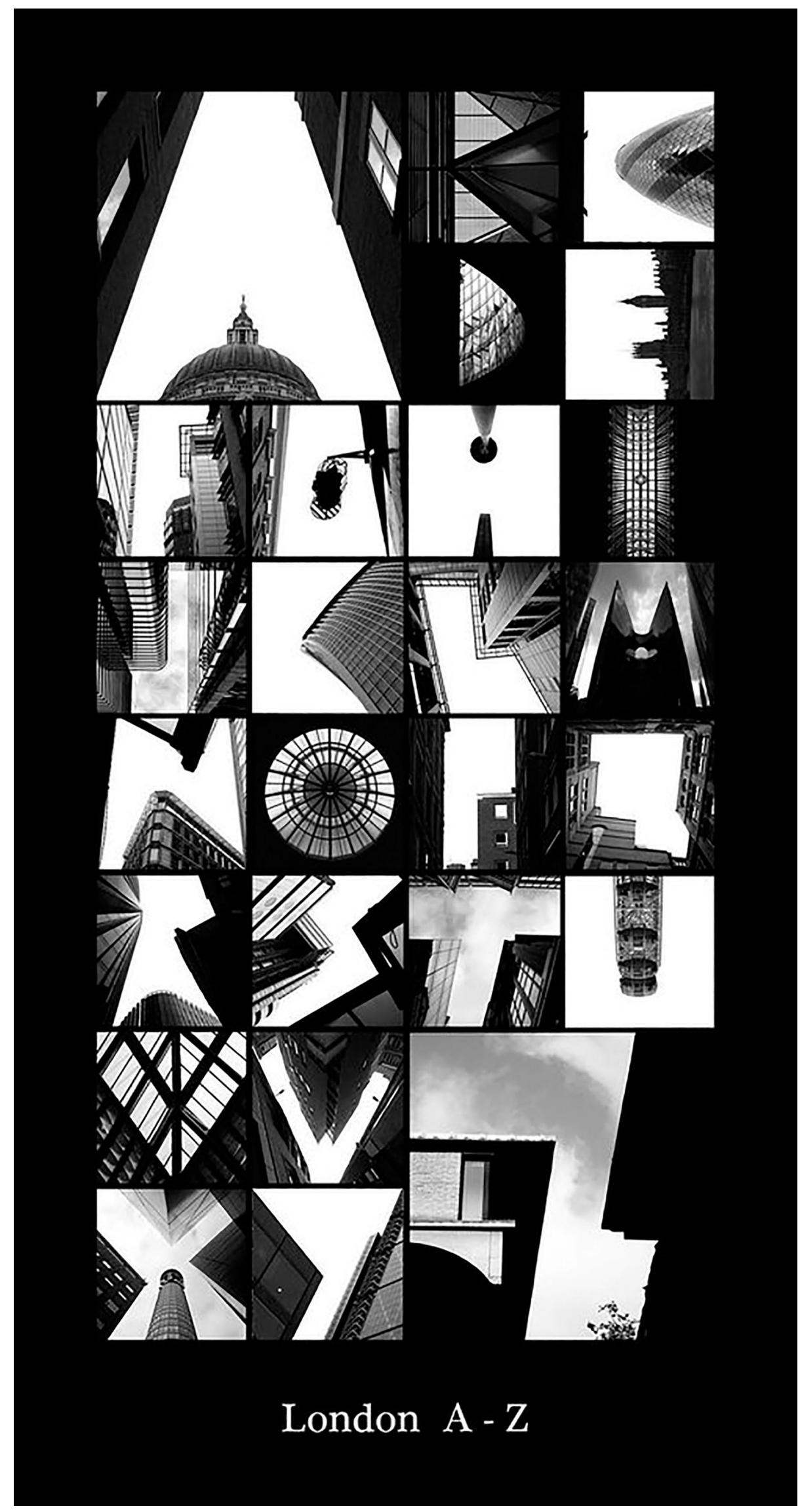

Fig. 6. Photo-graphic

visual language of Peter

project created with the

concept of 'proximity'

(2005-2010). 
from the inside out, given the subjects from the back (fig. 2), during the second half of the twentieth century the Polaroid device reverses the point of view by giving the 'window' a role of absolute protagonism: it becomes the frame through which the world observes man. This tool represented a fashion phenomenon during the 1950s, a real form of mass communication as well as constituting a completely original narrative art language. Before the great digital explosion today, it was back in vogue for several years and, currently, albeit as a niche phenomenon, the analog community of 'polaroiders' is increasingly vast.

In the digital age, the Polaroid is in fact inserted as a nostalgic element linked to the importance of instant technology but above all to its analogue nature and to the risk that, in the most basic hypothesis, photography either comes out well or is a total failure. And it is precisely this possibility that attracts many artists to use it. It represents a unique creative tool. There is no possibility of post-production and creativity is concentrated entirely in the application of simple and/or complex 'techniques', which allow to alter the shot taken through the chemical compounds contained within the films [Thormod Carr 1997] .

Even today the goal has not changed: the Polaroid is always intended as a means to tell something. In the last decades of the 1900s, this device takes a step forward and begins to take shape as a storyboard to define the personal vision of stronger images with a 'story' that unites everything. Think, for example, of the portraits of the painter, graphic artist and illustrator Andy Wharol (1928-1987), who through the use of Polaroid invented a revolutionary and very personal style, portraying with this device the protagonists of the cinema of his time and strengthening their 'iconic image' [Hunt 2007] (fig. 3), or to Julian Schnabel's large-format creations, which depicted familiar places and/or hugs with colleagues and friends according to a completely unconventional vision [Hollein 20 I 8] (fig. 4). This intimate representation of man will later lead the Polaroid Istant Photographer Maurizio Galimberti to the creation of 'artistic human (and architectural) mosaics' [Mutti 2005; Galimberti 20 I 8], broadening the horizons and the space of sight, breaking the usual patterns of vision and leading the eye to the decoding of a well-constructed narration of the subjects photographed through the juxtaposition of numerous windows, almost a step by step, which moves from the hair towards the face (fig. 5).

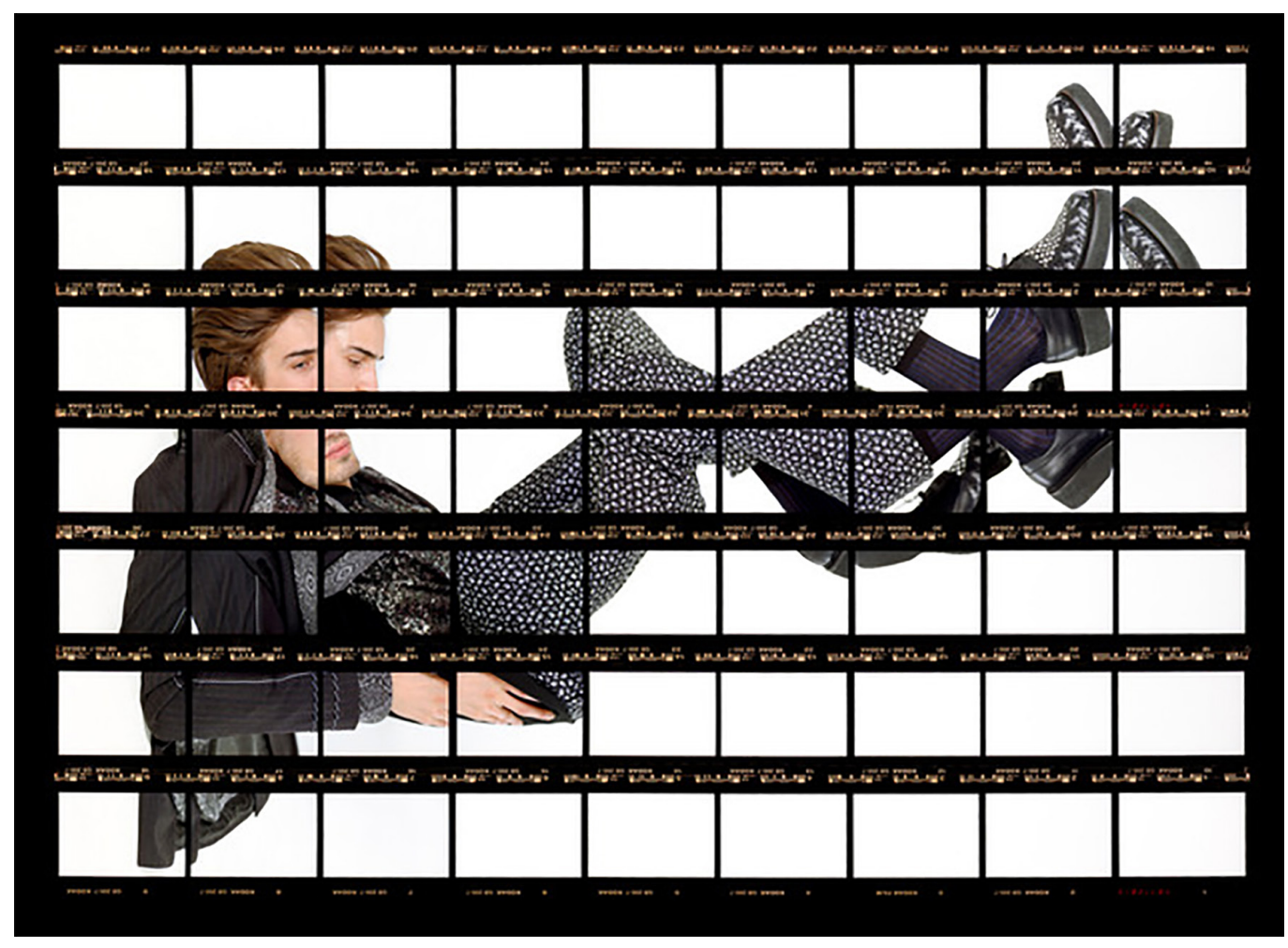


Since the last decade, the great explosion of computing (always in constant evolution) has brought these visual 'windows' towards an exclusively digital dimension. Just think, for example, of the works Alphatecture by Peter Defty (fig. 6) or Tango Metropolis by Thomas Kellner, the result of a perfect fusion of the different visual languages of photography (and also of typography in the first) (fig. 7), which they continued to narrate the filtered reality through the sensitivity informed by the culture of the person taking the shot according to a widely diffused communicative language originating from the analogue precursor.

The Polaroid can therefore and undoubtedly be considered one of the first visual language tools within everyone's reach. And, while on the one hand, he introduced an artistic culture based on introspection and the careful representation of human emotions, his photographic innovation also initiated the process of 'hurrying up', leading photography to no longer be the same patient work which was before his birth.

Finally, emblematic is today the global 'visual window' derived from it, which has literally invaded our daily sphere during the Covid-19 pandemic within communication and distance learning devices such as Microsoft Teams, Google Meet, Zoom, etc. (fig. 8). In these devices, each is 'framed' in a 'video-polaroid' of 'Galimbertian' derivation, which can be sensually enhanced through 'multidimensional sections' with a very wide range of options. This phenomenon, deeply rooted in our daily life, has even surpassed the standardized grid of the message boards of social networks. Hence, even if in a virtual dimension, anyone can be anywhere in the world or, in company in a virtual room, to replace today's "drama of alienation (...) from the ecstasy of communication" at a distance [Baudrillard, I997, p. II] (V.C.).

\section{The videoclip I'm a Picture as an integration between Polaroid and videography}

The idea of using a videographic spot, created as a Polaroid advertising product, arises from the application of the current concept of 'neighborhood' during the quarantine period [Treleani, Zucconi 2020] to the residential filter spaces featured in the videoclip.
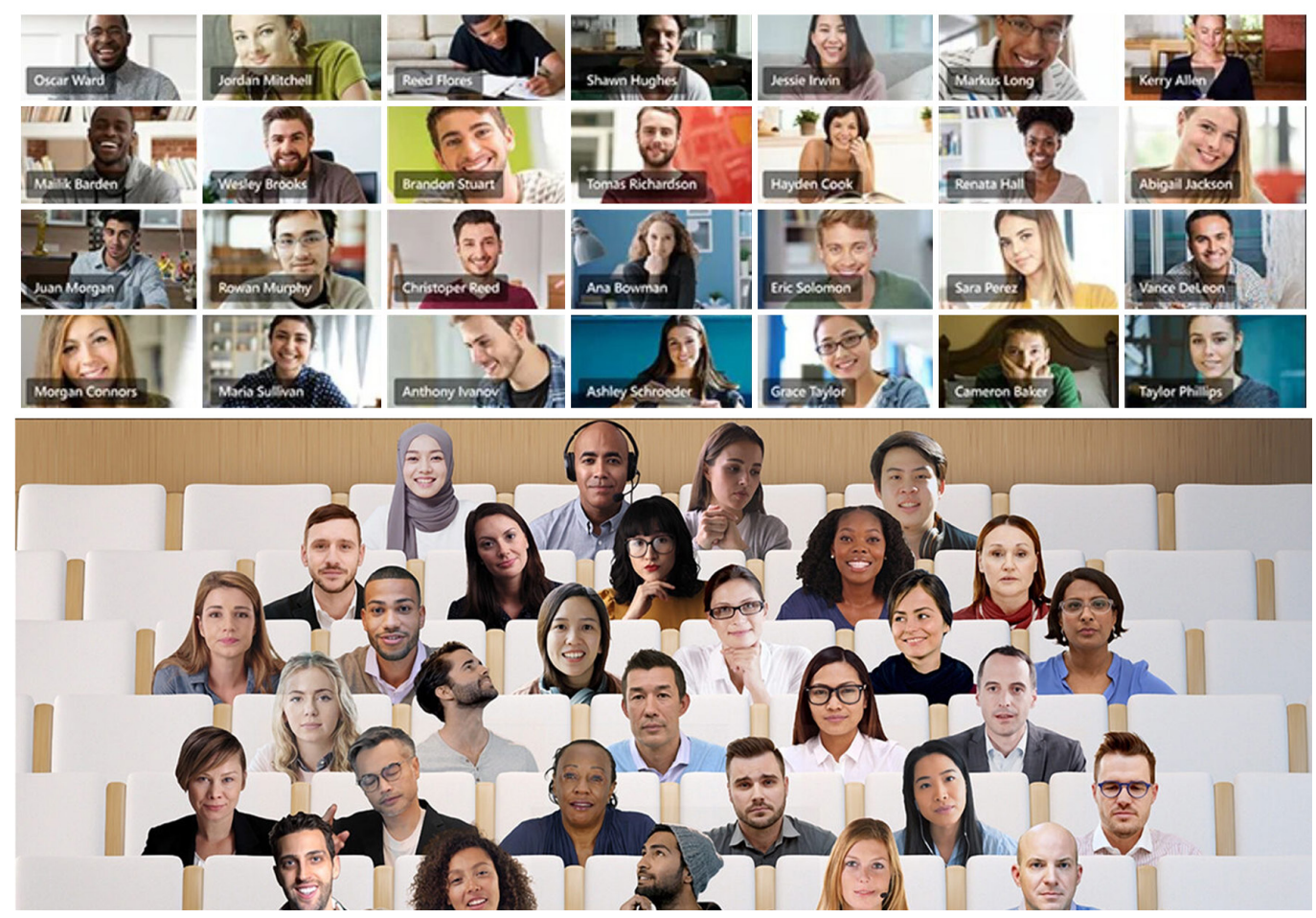


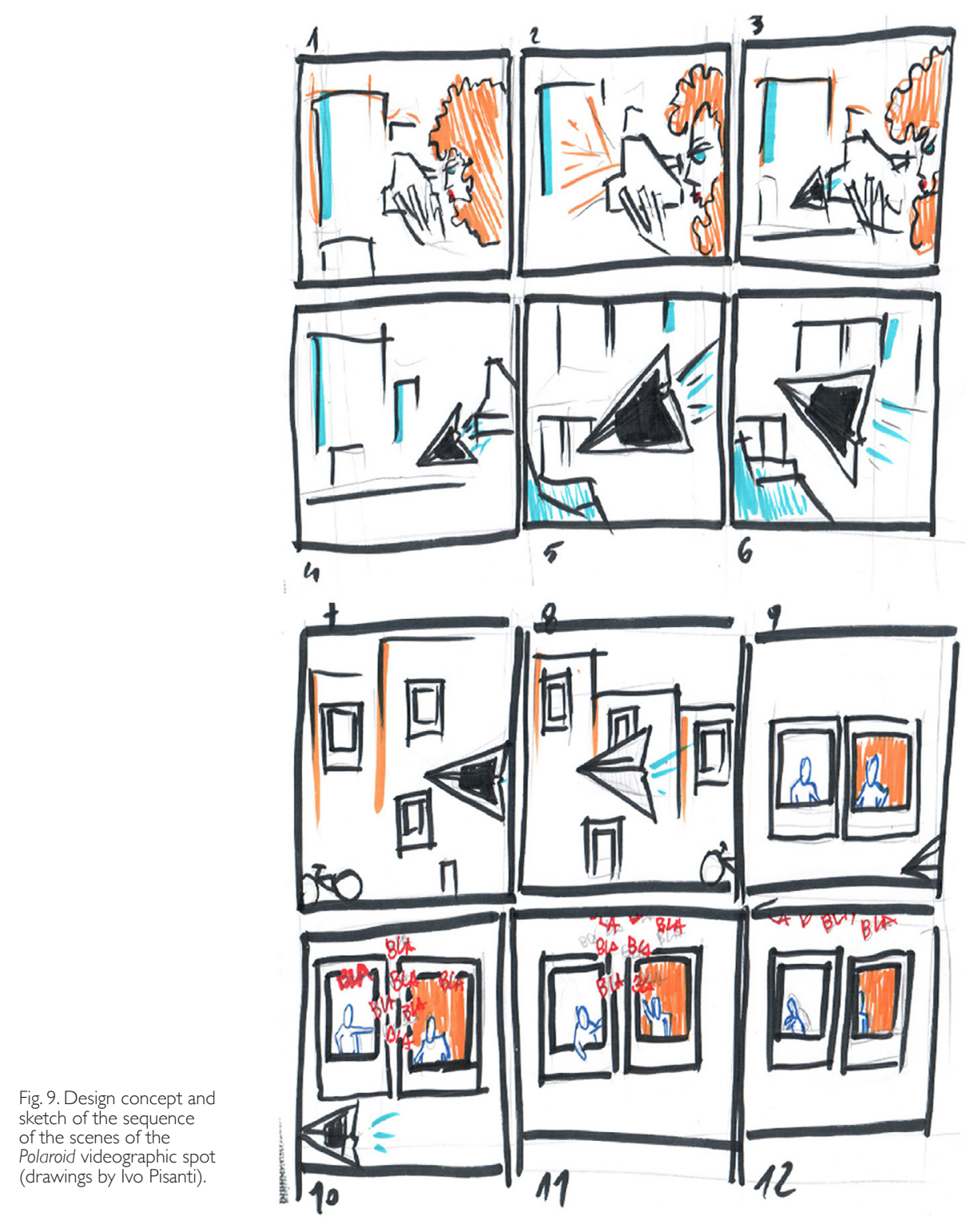

The project for the creation of the videoclip integrates several forms of communication in a single product: drawing (analog and digital), for the creation of the scenes (fig. 9); vector reproduction of graphic elements for the connection of the aforementioned scenes; the photographic shots, taken with a Canon camera and edited with the stop motion technique; the accompanying sound context [Falcidieno 2006; 2008; 20 I0; Zerlenga 2007; 2020; Cirillo 2019]. The videoclip was then edited and assembled with special video and music editing programs.

The story starts with the scene of a girl who is taking a Polaroid photo. The photograph slips from the shield of the device transforming itself into a paper plane. The plane begins to fly into the room to continue on a white wall where, quickly, numerous linear graphic signs gradually take the form of several buildings seen from the front. The paper plane slips into one of the numerous windows (represented by the Polaroid frames), which make up the facades of the buildings in the neighborhood, and the scene comes to life recalling the theme of the 'neighborhood' through scenes of everyday life set in the spaces of filter of windows and balconies. These filter places are also promoters of remote visual and verbal communication. In this sense, through the development of an adver- 
tisement for a vintage product, the Polaroid, in fact, the urban environment and everyday life aim to re-evaluate the daily spaces long abandoned by the frenzy of pre-pandemic. Subsequently, the scenes follow one another in a multiplicity of daily narratives, which are linked together according to interpersonal relationships 'at a distance'. The scenes, observed from the outside, are connected to each other through animated drawings such as the basket, hearts, musical notes, the onomatopoeia of speaking now symbols of everyday life Covid- 19. Finally, a ribbon in Polaroid colors emerges from a room, in which a girl is about to sing, and concludes the story by positioning herself under the camera and composing the slogan (fig. I0).

The creation of the sets took place with the stop motion technique (and not via video) [Gasek 2017] in order not to stray too far from the 'photographic' and communicative style of the device (fig. II). For the video-spot, a sound accompaniment with a cadenced rhythm was also created so as to remain imprinted in the mind almost like a rhyme to be hummed. The same phrase is sung four times by both a solo voice and a festive choir. The latter recalls a message of collective sharing and refers to the choirs on the balconies during the first lockdown (fig. 12). The musical piece was composed entirely by Ivo Pisanti, then mixed and recorded by Marco Musco and a choir of seven young people. The backing track was created with the GarageBand music editing program, to which the voices recorded in the recording studio were subsequently added. Formulated to be easily memorized, the lyrics of the song (and the videospot slogan) allude to the current consumption of images on social networks (where, by now, one is an image of oneself) [Menchetelli 2019] and reads "I'm a Picture, we are a Picture. I wanna Picture, picture of me" (O.Z.).

Fig. 10.Vector reproduction of the neighborhood scene and the the graphic elements connecting the Polaroid windows (drawings by Ivo Pisanti).
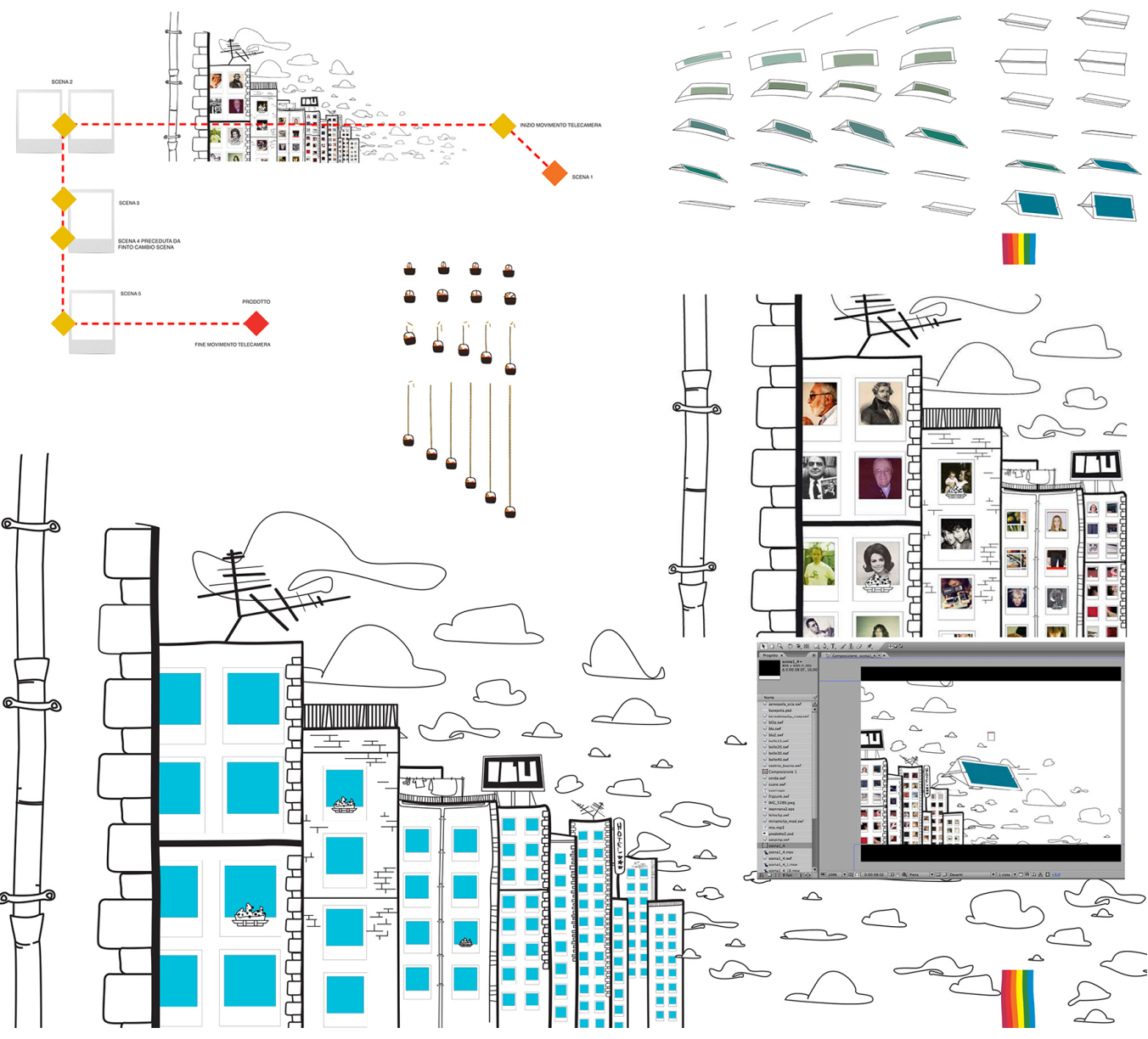

III

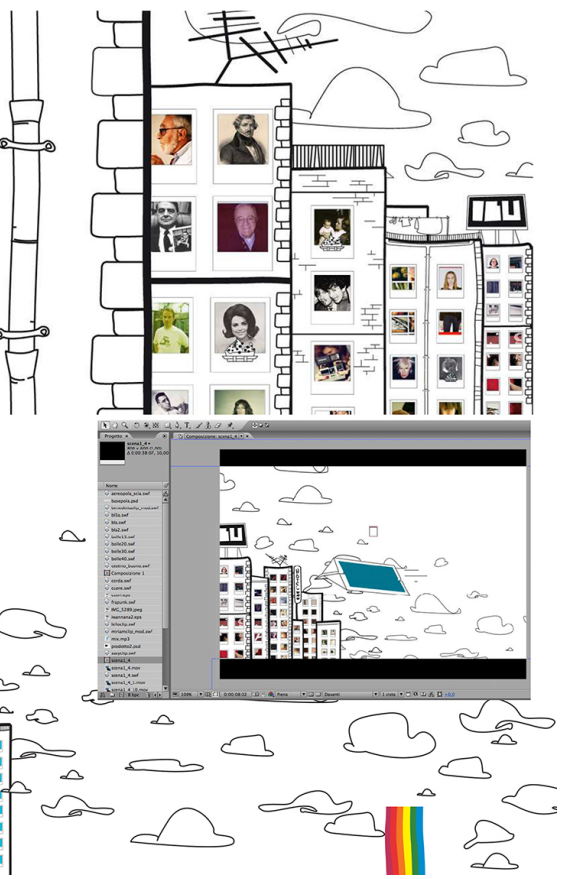




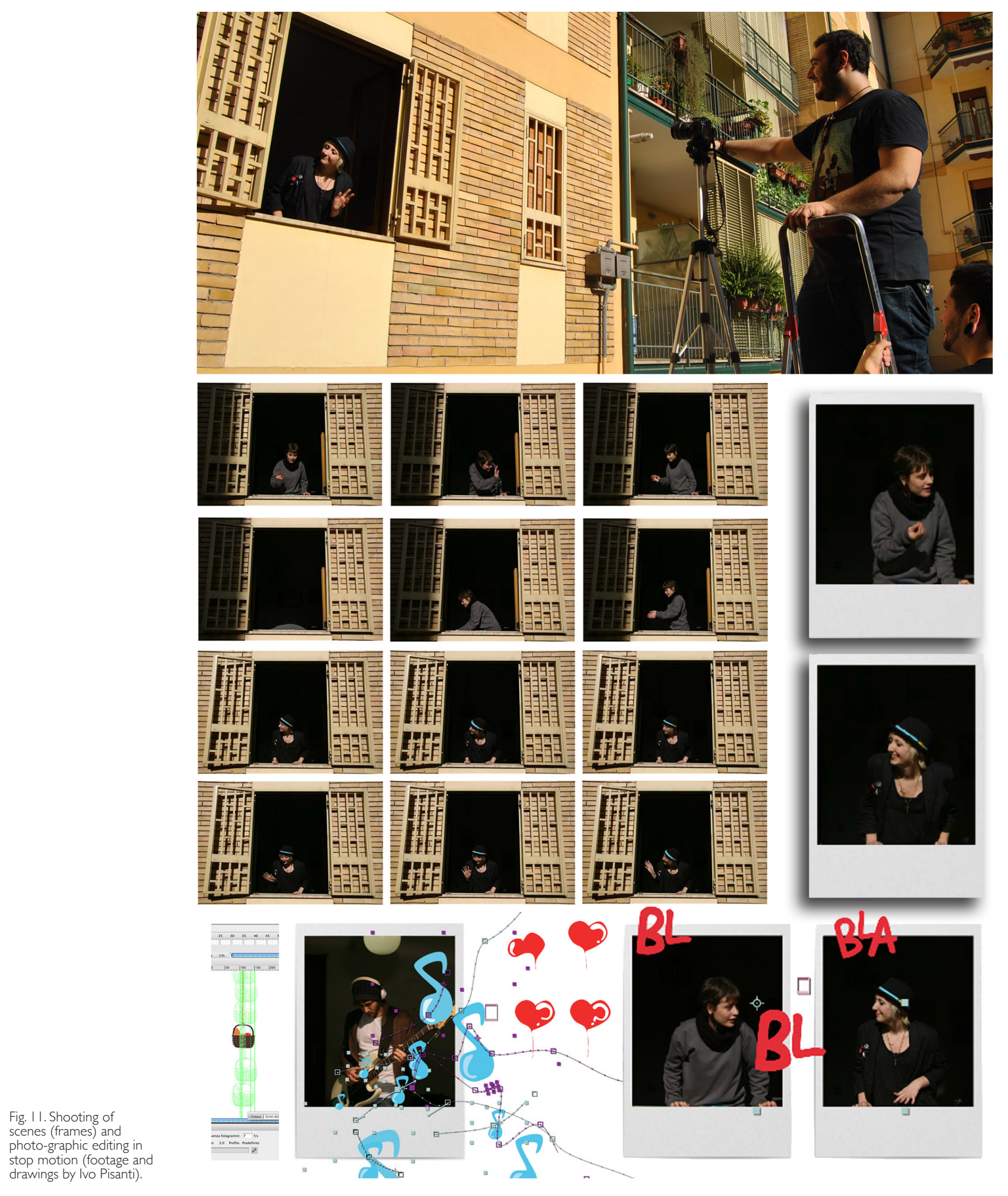




\section{Conclusions}

The theme of the connection between languages, technologies and distances was developed as a metaphor through the creation of a multimedia product in which drawing (in its many forms) was the main form of communication in the story told. The project, carried out in a university context [ $\mathrm{I}$ ], is configured as an advertising videoclip of the Polaroid analog device, whose audiovisual narration experiments the creative relationship between drawing (analog-digital) and photography in the cultural opinion that, at the time of the pandemic, the city has moved to the neighborhood spaces and to the filter places pertinent to them, to be understood as an opportunity for multifunctional re-design (O.Z.).
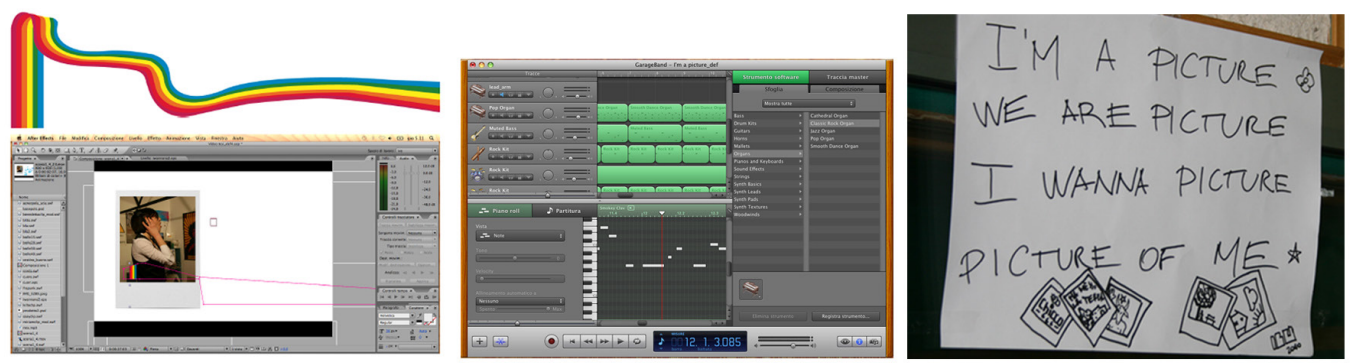

Fig. 12. Design of the sound accompaniment and video sequence of the commercial (elaborations by
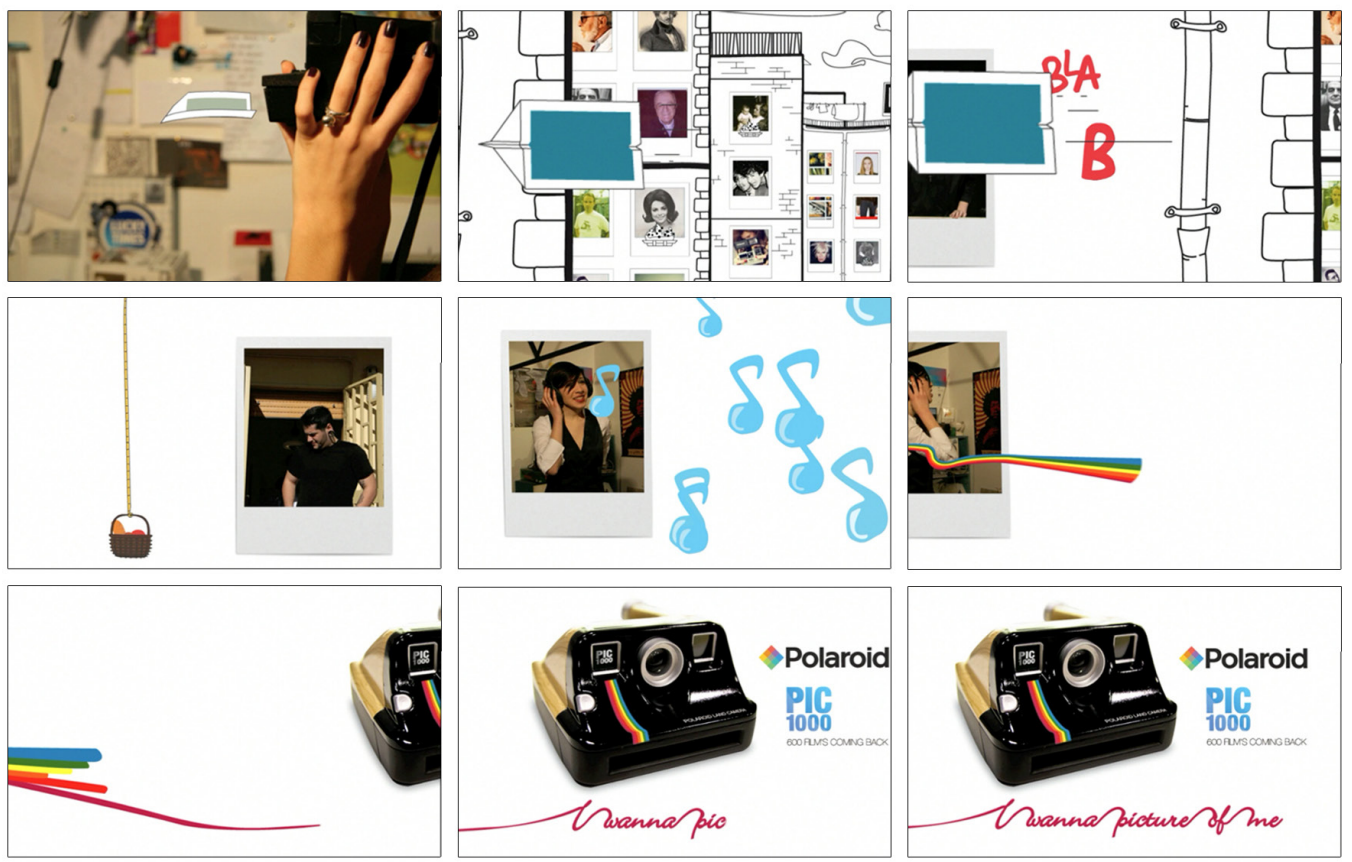

Notes

[I] With the scientific coordination of Ornella Zerlenga, the project was developed within the Graphic Creations Laboratory by Ivo Pisanti (figs. 9-12).

\section{References}

Baudrillard J. (1997). L'altro visto da sé. Genova: Costa\&Nolan, p. I I. Ed. orig. 1987. L'autre par lui-Meme: Habilitation. Paris: Editions Galilèe.

CirilloV. (20 |9). Scrittura e multimedialità. Ridisegnare l'esperienza futurista |Writing and Multimedia. Redesigning the Futuristic Experience. In diségno, vol. 4, pp. I49-160.

Cirillo V.,Todisco I. (a cura di). (2020). Cratere degli Astroni. Concorso grafico 'Comunicazione etica per il pianeta'. Napoli: La Scuola di Pitagora. 
De Rubertis R. (1994). Il disegno dell'Architettura. Roma: La Nuova Italia Scientifica.

Earls A., Rohani N. (2005). Images of America Polaroid. Chicago: Arcadia Publishing.

Falcidieno M. L. (2006). Parola disegno segno. Comunicare per immagini. Segno, significato, metodo. Firenze: Alinea.

Falcidieno M. L. (2008). Il ruolo del disegno nella comunicazione. Firenze: Alinea.

Falcidieno M. L. (20I0). Comunicazione-rappresentazione. Testo, immagine, segno grafico. Firenze: Alinea.

Ford S., Forlizzi J., Ishizaki, S. (1997). Kinetic Typography: Issues in time-based presentation of text. In CHI97 Conference Extended Abstracts, pp. 269-270.

Galimberti M. (2018). Maurizio Galimberti. Ediz. Illustrata. Torino: FIAF.

Gasek T. (2017). Frame-By-Frame Stop Motion: The Guide to Non-Puppet Photographic Animation Techniques. Second Edition. Boca Raton: CRC Press.

Ghirri P. (Ed.). (1998). Luigi Ghirri - Polaroid - L'opera completa 1979-1983. Milano: Baldini\&Castoldi, p. 23.

Gombrich E. (1994). The Image and the Eye. London: Phaidon Press.

Hollein M. (2018). Julian Schnabel: Symbols of Actual Life. San Francisco: Fine Arts Museums of San Francisco.

Hunt T. (2007). Andy Warhol Polaroid Portraits. Tokyo: Miyake Fine Art.

Kathleen T. Carr (1997). Polaroid Transfers: A Complete Visual Guide to Creating Image and Emulsion Transfers. New York:Amphoto.

Menchetelli V. (2019). Images and more images. In img journal, I ( I), 206-2I 3.

Munari B. (20 I0). Da cosa nasce cosa. Roma: Laterza.

Mutti R. (2005). Maurizio Galimberti. Metacittafisica. Roma: Contrasto DUE.

Paoloni M., Tutino M. (a cura di). (2020). L'Italia ai tempi del Covid- 19. Tomo I. Milano: Wolters Kluwer Italia.

Spera M. (200 I). La progettazione grafica tra creatività e scienza. Roma: Gangemi editore.

\section{Authors}

Ornella Zerlenga, Università degli Studi della Campania Luigi Vanvitelli, ornella.zerlenga@unicampania.it

Vincenzo Cirillo, Università degli Studi della Campania Luigi Vanvitelli, vincenzo.cirillo@unicampania.it

To cite this chapter. Zerlenga Ornella, Cirillo Vincenzo (2021). La tecnologia Polaroid fra linguaggi e distanze. Una suggestione videografica per i tempi di Covid-19/Polaroid Technology between Languages and Distances. A Video-graphic Suggestion for the Covid-19Times. In Arena A., Arena M., Mediati D., Raffa P. (a cura di). Connettere. Un disegno per annodare e tessere. Linguaggi Distanze Tecnologie. Atti del $42^{\circ}$ Convegno Internazionale dei Docenti delle Discipline della Rappresentazione/Connecting. Drawing for weaving relationship. Languages Distances Technologies. Proceedings of the 42th International Conference of Representation Disciplines Teachers. Milano: FrancoAngeli, pp. $1294-1317$. 